\title{
TRIBUTAÇÃO INCONSTITUCIONAL DO IMPOSTO DE TRANSMISSÃO SOBRE BENS IMÓVEIS: O CONFRONTO ENTRE O DIREITO REAL DE PROPRIEDADE E O COMBATE À EVASÃO FISCAL
}

Ana Júlia Ferraz Pozo Maturano

\section{INTRODUÇÃO}

O presente trabalho discorrerá acerca da cobrança antecipada do Imposto sobre Transmissão de Bens Imóveis e sua manifesta inconstitucionalidade. A Constituição Federal garantiu aos Municípios a faculdade de tributar a transmissão inter vivos de bens imóveis a qualquer título: por ato oneroso, por natureza ou acessão física, bem como de direitos reais sobre imóveis, exceto os de garantia, e a cessão de direitos a sua aquisição, nos termos do artigo 156 da Carta Magna, in litteris:

Art. 156. Compete aos Municípios instituir impostos sobre (...)

II - transmissão “inter vivos”, a qualquer título, por ato oneroso, de bens imóveis, por natureza ou acessão física, e de direitos reais sobre imóveis, exceto os de garantia, bem como cessão de direitos a sua aquisição;

Ocorre que na ânsia de garantir o pagamento do referido tributo, alguns municípios acabam por exigir que este seja recolhido quando da celebração do negócio jurídico de compra venda - em alguns casos a exigência do pagamento alcança ainda as promessas de compra e venda.

Não obstante ser pacificado o momento em que ocorre a transferência da propriedade - a saber, com o registro do imóvel no Registro Geral de Imóveis, alguns municípios cobram o aludido tributo de forma antecipada em razão de presumirem que quando da celebração do negócio jurídico há capacidade contributiva futura do adquirente do imóvel. Contudo, tal presunção é indevida em virtude da celebração do negócio jurídico não possuir o condão de - lê-se, não ser eficaz para 
•• Tributação, direitos fundamentais e desenvolvimento

- transferir a propriedade do bem, porquanto se dá em momento prévio ao do referido registro e, por conseguinte, com ele não se confunde.

Ao instituir o ITBI antecipadamente os municípios visam a combater fraudes e evasão fiscal.

No entanto, tal combate é realizado de maneira equivocada por ignorar e burlar o momento correto de ocorrência do fato gerador do ITBI, o que torna a cobrança eivada de vício de constitucionalidade, vez que se tem por violado o que estabelece o artigo 156 da Constituição Federal supracitado.

A principal e mais gravosa consequência desta violação é a afronta ao direito real por excelência, o direito de propriedade, exarado no inciso XXII do artigo $5^{\circ}$ da Carta Maior, que, muito embora não seja direito absoluto - já que estes inexistem no Estado Democrático, não pode sofrer limitações ou restrições sem que estas sejam alicerçadas em outros princípios constitucionais, de forma que nunca por interesses econômico-financeiros dos entes políticos e dos poderes públicos.

Sabe-se que é de suma importância o planejamento tributário dos entes políticos no sentido do combate às fraudes e sonegação de impostos, práticas endêmicas que maculam o erário e sua destinação. No entanto, em alguns casos as vias utilizadas em tal combate não se coadunam com as normas preceituadas pela Constituição Federal, bem como pela legislação infraconstitucional, razão pela qual o presente estudo se justifica.

Recolher o Imposto Sobre Transmissão de Bens Imóveis em momento anterior à ocorrência do seu fato gerador é uma notória tentativa de evitar que os adquirentes de bens imóveis deixem de pagar o tributo devido. Porém, ao ignorar que a efetiva transferência da propriedade do imóvel ainda não se perfez, vez que esta se concretiza apenas com o registro do bem no Registro Geral de Imóveis, como já dito alhures, faz com que a ordem de cobrança do referido imposto se torne inconstitucional.

Neste sentido, é necessário que os Municípios apliquem formas diversas de combater as fraudes, e que sejam eficazes, sem que seja preciso apelar para a inconstitucionalidade e afronta ao direito real de propriedade, formas estas das quais os contribuintes precisam estar cientes com vistas a poderem evitar a violação de um de seus principais direitos fundamentais.

Objetiva-se, então, constatar que o combate às fraudes fiscais pelos Municípios deve ser realizado de outras maneiras por meio do estudo das práticas incons- 
titucionais que por estes entes da federação vêm sendo utilizadas para que a cobrança do ITBI se dê da forma devida e prevista e lei, sem que haja afronta ao direito de propriedade.

\section{DA REGRA MATRIZ DE INCIDÊNCIA DO ITBI}

\subsection{Critérios material, pessoal, quantitativo e espacial}

A Constituição Federal no inciso II do art. 156 outorga aos Municípios a competência tributária para instituição do chamado Imposto sobre Transmissão Inter Vivos de Bens Imóveis e de Direitos Reais a eles relativos, nos seguintes termos:

Art. 156. Compete aos Municípios instituir impostos sobre:

II - transmissão “inter vivos", a qualquer título, por ato oneroso, de bens imóveis, por natureza ou acessão física, e de direitos reais sobre imóveis, exceto os de garantia, bem como cessão de direitos a sua aquisição;

A transmissão inter vivos, conforme Leandro Paulsen "é a transferência do direito de uma pessoa a outra por força de um negócio jurídico. Não se confunde com a aquisição originária da propriedade, que não se sujeita à incidência deste imposto porque não implica transmissão." Por disposição do art. 1227 do Código Civil, a transmissão ora tratada se perfaz com o registro do respectivo título (como a escritura de compra e venda) no Cartório de Registro de Imóveis.

Desta forma, quanto ao critério material do ITBI, o legislador ordinário pode erigir como hipótese de incidência três situações, quais sejam, a) a transmissão inter vivos, a qualquer título, por ato oneroso, de bens imóveis por natureza ou acessão física; b) a transmissão de direitos reais sobre imóveis, exceto os de garantia; c) a cessão de direitos à sua aquisição. Assim, a transmissão deve ocorrer por ato oneroso, isto é, sem o qual estar-se-ia diante de doação (salientando que, em regra, a cláusula de encargo nas doações não é suficiente para caracterizar um ato oneroso); o bem deve ser imóvel por natureza ou ter se aderido ao imóvel (a propriedade do solo abrange o solo, o espaço aéreo e o subsolo) e, por fim, deve-se estar diante de um ato inter vivos, porquanto o ato causa mortis é tributado por competência estadual pela instituição do Imposto sobre Transmissão Causa Mortis ou Doação ITCMD.

PAULSEN, Leandro. Curso de Direito tributario completo. 4. ed. rev. atual. e ampl. Porto Alegre: Livraria do Advogado, 2012, p. 245. 
-• Tributação, direitos fundamentais e desenvolvimento

Quanto à primeira hipótese de incidência, esta ganhará enfoque neste trabalho. Tal hipótese versa acerca da transmissão de direitos reais sobre imóveis, exceto os de garantia, salientando que os direitos reais caracterizam-se pela existência de uma obrigação passiva universal que tem efeito erga omnes, isto é, válida de forma indistinta a toda a sociedade. Nos termos do art. 1225 do Código Civil de 2002

Art. 1.225. São direitos reais:

I - a propriedade;

II - a superfície;

III - as servidōes;

IV - o usufruto;

$\mathrm{V}$ - o uso;

VI - a habitação;

VII - o direito do promitente comprador do imóvel;

VIII - o penhor;

IX - a hipoteca;

$\mathrm{X}-\mathrm{a}$ anticrese.

$\mathrm{XI}$ - a concessão de uso especial para fins de moradia;

XII - a concessão de direito real de uso.

XIII - a laje. (Incluido pela Lei n. 13.465, de 2017).

Cumpre apontar que os direitos reais de garantia, sejam estes o penhor, a hipoteca e a anticrese, previstos nos incisos VIII, IX e X não são tributáveis pelo ITBI, estando fora de seu critério material.

Em seu aspecto pessoal o sujeito ativo do tributo é o Município de situação do bem, como é colocado pelo artigo 156 da Carta Maior retrotranscrito, correspondendo ao território da pessoa política tributante. $\mathrm{O}$ critério pessoal quanto ao sujeito ativo coincide com o critério espacial, neste também presente o município. Isto porque a extraterritorialidade da tributação municipal acarretaria em invasão da competência dos demais municípios, o que é defeso por lei, ainda que não haja critérios razoáveis para dirimir conflitos de competências horizontais - nos quais há bens que se situam em mais de um município. Ademais, é de suma importância a afirmação de Aires Barreto no sentido de que "diversamente do que ocorre com o IPTU e ITR, no ITBI não há distinção entre zona urbana e rural, valendo, pois, para todo e qualquer imóvel situado no território do Município". O art. 41 do CTN faz previsão semelhante ao $156, \$ 2^{\circ}$, II da Carta Maior. 
Quanto ao sujeito passivo, o art. 42 do Código Tributário Nacional define que "contribuinte do imposto é qualquer das partes na operação tributada, como dispuser a lei", o que significa que há para os sujeitos passivos a possibilidade de discutir quem irá cumprir com a obrigação tributária principal. $\mathrm{O}$ cenário mais comum que se observa na prática, em se tratando de compra e venda, é que o polo passivo da obrigação seja assumido pelo adquirente permutantes ou cedentes, $m u$ tatis mutandis, isto é, em regra, quem dispõe do direito ou bem assume o encargo de pagar o tributo. Todavia, isso pode ser alterado em conformidade com o disposto no CTN.

O critério quantitativo encontra sua base de cálculo no art. 38 do CTN, o qual estabelece que o cálculo do tributo será efetuado sobre o valor venal dos bens ou direitos transmitidos. Aqui se faz oportuna a indagação a respeito do valor do IPTU. Em virtude de o CTN instituir a mesma base de cálculo para ambos os impostos, não haveria razões para que seus valores fossem diferentes. Ocorre que o Superior Tribunal de Justiça reformou acórdão do Tribunal de Justiça de São Paulo o qual considerou que o artigo 33 do Código Tributário Nacional, que trata do IPTU, e ainda o artigo 38 do mesmo código, que cuida dos impostos sobre transmissão de bens (ITBI e ITCMD), ao definirem o valor venal como base de cálculo, alijam, por conseguinte, a coexistência de dois valores venais - um para o IPTU e outro para o ITBI. Em sede de recurso ao STJ, o município de São Paulo sustentou que a decisão estadual violou o artigo 38 do CTN, já que o valor venal, base de cálculo do ITBI, equivale ao de venda do imóvel em condições normais do mercado.

Isto porque os municípios estabelecem Plantas Genéricas de Valores - PGVs as quais orientam-se por critérios gerais que delineiam quais serão os valores de cada imóvel de acordo com suas características, ou ainda valem-se de Plantas Fiscais de Valores, essas utilizadas com vistas a calcular, além do IPTU, o ITBI. A súmula 110 do STJ preconiza que "o Imposto de Transmissão Inter Vivos não incide sobre a construção, ou parte dela, realizada pelo adquirente, mas sobre o que tiver sido construído ao tempo da alienação do terreno", o que é válido, desde que não implique base de cálculo superior ao real valor de cada imóvel. ${ }^{2}$

As alíquotas são fixadas pela legislação municipal, de modo que a Constituição Federal deixou de prever a fixação de limite por Resolução do Senado (hoje

PAULSEN, Leandro. Op. cit., p. 246. 
•• Tributação, direitos fundamentais e desenvolvimento

previsto apenas para o ITCMD). No tocante à sua progressividade, duas correntes versam a respeito. A primeira admite ser possível a progressividade das alíquotas do ITBI com fundamento no princípio da capacidade contributiva previsto no art. $145, \$ 2^{\circ}$ da Constituição Federal. Entende com muita acuidade a primeira corrente que o princípio da capacidade contributiva autoriza, ainda que de forma genérica, a progressão dos impostos. Em se tratando de um tributo de natureza real assim como o ITBI, o IPTU e o ITR também possuem alíquotas progressivas, o que afasta o argumento de que tributos reais não admitem progressividade.

A segunda corrente considera impossível haver progressividade nas alíquotas do ITBI, sob o fundamento de que a Constituição Federal já delimitou o arquétipo de cada tributo, prevendo, quando cabível, a progressividade, e destacando que o princípio da capacidade contributiva não se opera pela progressividade, mas pela proporcionalidade. Neste diapasão, a progressividade apenas seria admitida em se tratando de impostos reais, para o cumprimento de uma função extrafiscal como era o caso do IPTU, que em ode à função social da propriedade é instituído de forma progressiva, conforme explicitado neste trabalho, aos contribuintes que mantiverem suas propriedades em desconformidade com o plano diretor do município, não lhe dando destinação adequada, nos termos do artigo $182, \$ 4^{\circ}$, II da Constituição Federal.

Todavia, com a redação dada ao $\$ 1^{\circ}$ e incisos do artigo 156 da Lei Maior pela Emenda Constitucional n. 29/2000, passou-se a admitir a progressividade até mesmo fiscal do referido tributo Municipal em razão do valor do imóvel, de sua localização e de seu uso.

A progressividade do ITBI foi entendida como inconstitucional no ano de 2003, com a edição da Súmula 656 do STF, que tem por lógica a não aplicação aos impostos reais do princípio da capacidade contributiva, nos seguintes termos: "É inconstitucional a lei que estabelece alíquotas progressivas para o imposto de transmissão "inter vivos" de bens imóveis - ITBI, com base no valor venal do imóvel." Ocorre que o STF, em recente decisão que versava acerca do ITCMD (RE 562045/RS), alterou a interpretação do artigo 145, 1º, da Constituição Federal, passando a dispor que a capacidade contributiva é aplicável a todos os impostos, pessoais ou reais, porquanto seja possível aferir a capacidade econômica do contribuinte, não havendo motivos que obstem a progressividade desta última categoria de impostos. 
A votação não fora unânime. Contudo, a posição que prevalecera tomou por fundamento interpretação contrária ao que até então vinha sendo consolidado pela jurisprudência, preconizando que:

O entendimento de que a progressividade das alíquotas do Imposto de Transmissão Causa Mortis e Doação - ITCMD seria inconstitucional decola (...) da suposição de que esse $\$ 1^{\circ}$ do artigo 145 a admite exclusivamente para os impostos de caráter pessoal". A redação dada traria duas proposições distintas no referido artigo: I) que os impostos deveram sempre que possível ter caráter pessoal e II) os impostos deverão ser graduados segundo a capacidade contributiva (todos eles). Para Eros Grau, ainda, em voto vencedor "o $\$ 1^{\circ}$ do artigo 145 da Constituição determina como devem ser os impostos, todos eles. Não somente como devem ser alguns deles. Não apenas como devem ser os impostos dotados de caráter pessoal. Isso é nítido. Nítido como a luz solar passando através de um cristal, bem polido" ${ }^{3}$

Assim, conclui-se que, a súmula 656 do STF ainda se aplica ao ITBI. No entanto, a mudança do entendimento da Corte acerca da aplicação do princípio da capacidade contributiva a todos os impostos, torna constitucional a progressividade dos impostos reais, de modo que o objeto e redação da referida súmula restam prejudicados.

\subsection{Do critério temporal - momento de ocorrência do fato gerador do ITBI}

Aqui se encontra um dos celeumas deste trabalho, em razão do qual se apresenta necessária uma análise apartada em relação aos demais critérios da regra matriz de incidência do ITBI. O momento em que ocorre a hipótese de incidência do tributo (por melhor dizer, quando a situação elencada pelo legislador como passível de incidência de determinado tributo se materializa e ocorre no mundo fático, passando a ser denominado fato gerador, ou na melhor terminologia adotada pelo professor Paulo de Barros Carvalho ${ }^{4}$, fato jurídico tributável).

$\mathrm{O}$ art. 114 do CTN preleciona que "Fato gerador da obrigação principal é a situação definida em lei como necessária e suficiente à sua ocorrência.” de modo que é possível inferir que a hipótese de incidência tributária encontra-se no campo abstrato, sendo necessária e suficiente a descrição legal da situação em que o tribu-

3 BRASIL. Supremo Tribunal Federal. Recurso Extraordinário 562045/RS. Publicação DJe 27/11/2013. Rel. Min Ricardo Lewandowski.

4 CARVAlHO, Paulo de Barros. Curso de direito tributário. 23. ed. São Paulo: Saraiva, 2010, p. 255. 
•• Tributação, direitos fundamentais e desenvolvimento

to é devido, enquanto o fato gerador representa a ocorrência no mundo concreto de tal situação descrita na lei. ${ }^{5}$

Uma vez praticado o ato jurídico legalmente disposto ou celebrado o negócio erigido na lei em fato gerador, surge a obrigação para com o Fisco, e esta que subsiste independentemente da validade ou invalidade do ato praticado, porquanto o direito tributário emprega a interpretação objetiva do fato gerador, nos termos do art. 118, II do CTN, traduzida no brocardo pecunia non olet - dinheiro não tem cheiro. ${ }^{6}$

Como exemplo de tal máxima, tem-se a legislação brasileira do Imposto de Renda, segundo a qual todos aqueles que auferem renda ou de proventos de qualquer natureza poderão ser chamados a integrar o polo passivo da relação tributária, abstraindo-se a denominação jurídica de seus rendimentos, títulos ou direitos. $\mathrm{O}$ art. 26 da Lei n. 4.506/64 dispõe que: "os rendimentos derivados de atividades ou transações ilícitas, ou percebidas com infração à lei, são sujeitos à tributação sem prejuízo das sanções que couberem".

A jurisprudência corrobora com o entendimento consagrado pelo CTN, admitindo ser possível a tributação sobre rendimentos provenientes de atividade ilícita, seja de natureza civil ou penal, porque se o ato ou negócio ilícito for acidental à norma de tributação, surgirá com a obrigação tributária as consequências que lhe são inerentes. A propósito do assunto, a Suprema Corte entendeu ser legítima a tributação de produtos financeiros resultantes de atividades criminosas, nos termos do abalizado dizer do art. 118, I, do CTN, conforme a ementa abaixo:

Sonegação fiscal de lucro advindo de atividade criminosa: non olet. Drogas: tráfico de drogas, envolvendo sociedades comerciais organizadas, com lucros vultuosos subtraídos à contabilização regular das empresas e subtraídos à declaração de rendimentos: caracterização, em tese, de crime de sonegaçáo fiscal, a acarretar a competência da Justiça Federal e atrair pela conexão, o tráfico de entorpecentes: irrelevância da origem ilícita, mesmo quando criminal, da renda subtraída à tributação. A exoneração tributária dos resultados econômicos de fato criminoso - antes de ser corolário do princípio da moralidade - constitui violação do princípio de isonomia fiscal, de manifesta inspiração ética"7 (Grifos nossos).

Ibidem, p. 258.

SABBAG, EDUARDO. Manual de direito tributário. 8. ed. São Paulo: Saraiva, 2016, p. 1396.

BRASIL. Supremo Tribunal Federal. Habeas Corpus 77530/RS. Publicação DJe 18/09/1998.

Rel. Min. Sepúlveda Pertence. 
Neste sentido, no instante em que se dá a materialização da hipótese de incidência, nasce o liame jurídico entre o Fisco e o contribuinte, que torna este último obrigado a pagar a prestação pecuniária. Assim, discorre a respeito Hugo de Brito Machado

Não dispondo a lei de modo diferente, considera-se ocorrido o fato gerador e existentes os seus efeitos, (a) em se tratando de situação de fato, desde o momento em que se verifiquem as circunstâncias materiais necessárias a que se produzam os efeitos geralmente, ou ordinariamente, delas decorrentes, e (b) em se tratando de situação jurídica, desde o momento em que tal situação jurídica esteja definitivamente constituída, nos termos do direito aplicável.

Logo, tratando-se de situação de fato, o fato gerador se perfaz desde o momento em que as circunstâncias materiais produzem seus efeitos. Assim que praticada a ação determinada no fato gerador do tributo, este já existe e impóe o pagamento de uma prestação. Porém, tratando o fato gerador de uma situação jurídica, considerar-se-á ocorrido quando presentes os requisitos legais definidos na referida situação. Na situação jurídica condicional, ensina o art. 117, incisos I e II do CTN que o fato gerador considera-se ocorrido dependendo da condição; se a condição for suspensiva, desde o momento em que a condição for implementada, produzindo os efeitos do ato ou negócio; se a condição for resolutiva, desde o momento da prática do ato ou celebração negócio.

Quanto ao ITBI, o momento de ocorrência do fato gerador gera discussóes pois alguns consideram como devida a exação a partir do registro do bem imóvel no Registro Geral de Imóveis, momento apto a transferir a propriedade imobiliária, conforme disposição do art. 1245 do Código Civil, in verbis

Art. 1.245. Transfere-se entre vivos a propriedade mediante o registro do título translativo no Registro de Imóveis.

$\$ 1^{\circ}$ Enquanto não se registrar o título translativo, o alienante continua a ser havido como dono do imóvel.

$\$ 2^{\circ}$ Enquanto não se promover, por meio de ação própria, a decretação de invalidade do registro, e o respectivo cancelamento, o adquirente continua a ser havido como dono do imóvel (grifos nossos).

Outros entendem em sentido diverso, adotando um posicionamento que considera devido o imposto quando convencionado o negócio jurídico de compra e venda (efetivado o pagamento e a escritura pública), alegando que neste momento já foram produzidos os efeitos econômicos e já se revelou a capacidade contributiva do sujeito passivo, pois este tinha ciência, quando da celebração do negó- 
•• Tributação, direitos fundamentais e desenvolvimento

cio, da carga tributária à qual incidiria sobre o ato, e aperfeiçoou o negócio da mesma maneira.

Os doutrinadores que defendem a interpretação econômica e que acreditam que no Direito Tributário o importante é a realidade dos fatos econômicos entendem como o momento da ocorrência do fato gerador do ITBI o da escritura de compra e venda acabam por derrubar o princípio da segurança jurídica, pois defendem o a arrecadação deste tributo como um método de captação de riqueza vez que elegem como momento da ocorrência do fato gerador aquele que expressa a manifestação de riqueza.

É inescapável a constatação de que neste caso o Direito Tributário, no que tange à legislação do ITBI deve ser interpretado esvaziando-se a manifestação da capacidade contributiva, dado que já existe uma precisão jurídica acerca da transferência da propriedade plasmada na norma cível e de necessária aplicação à interpretação do critério temporal da regra matriz de incidência do tributo em estudo. Antecipar esta cobrança para o momento de convenção da compra e venda significa obrigatoriamente ferir o princípio da legalidade.

É o que está sujeito a ocorrer nos casos em que há cobrança de ITBI nos contratos de promessa de compra e venda de imóveis. Nestes, é pactuado que a propriedade será transferida ao promitente comprador, mas, não cabe a este pagar qualquer tributo no momento da promessa, tendo em vista que o negócio futuro pode não se consolidar, caso que não haverá fato imponível. É este o posicionamento adotado pelo Supremo Tribunal Federal em sede de Agravo Regimental em Recurso Extraordinário ${ }^{8}$, senão vejamos:

AGRAVO REGIMENTAL EM RECURSO EXTRAORDINÁRIO COM AGRAVO. IMPOSTO SOBRE TRANSMISSÃO DE BENS IMÓVEIS. FATO GERADOR PROMESSA DE COMPRA E VENDA. IMPOSSIBILIDADE. A obrigação tributária surge a partir da verificação de ocorrência da situação fática prevista na legislação tributária, a qual, no caso dos autos, deriva da transmissão da propriedade imóvel. Nos termos da legislação civil, a transferência do domínio sobre o bem torna-se eficaz a partir do registro. Assim, pretender a cobrança do ITBI sobre a celebração de contrato de promessa de compra e venda implica considerar constituído o crédito antes da ocorrência do fato imponível. (Grifos nossos)..

BRASIL. Supremo Tribunal Federal. Agravo Regimental em Recurso Extraordinário com Agravo 805859/RJ. Publicação DJe 09/03/2015. Rel. Min. Luis Roberto Barroso. 
Isto porque o compromisso de compra e venda não transmite direitos reais tampouco configura cessão de direitos à aquisição deles. $\mathrm{O}$ mesmo ocorre com leis municipais que preveem o pagamento do imposto na chamada cessão de direitos aquisitivos, que ocorre quando o comprador de um imóvel na planta cede a futura propriedade a outro interessado antes da entrega do bem. Como exemplo, o imóvel pode ser comprado para mero investimento, ou ainda o comprador pode descobrir que não poderá mais arcar com outros custos. O Supremo Tribunal Federal já entende que o ITBI não é devido em tais situações.

Feito o panorama a respeito do Imposto de Transmissão sobre Bens Imóveis Inter Vivos cabe a partir deste momento analisar os aspectos da propriedade em si, pois a ânsia do ente municipal por arrecadar o tributo em momento anterior ao disciplinado por lei fere, além dos princípios do direito já citados, o direito de propriedade abalizado pela Constituição Federal que, embora não possua caráter absoluto (como nenhum direito previsto hodiernamente), se configura como direito real por excelência cuja infração implica em ato inconstitucional. Após as explicações a respeito do instituto da propriedade, restará manifesta a inconstitucionalidade e ilegalidade na cobrança o ITBI antes do requerido Registro, assunto também abordado mais adiante.

\section{PROPRIEDADE: CONCEITO, POSITIVAÇÃO E LIMITAÇÕES}

Por obra da noção jurídica da propriedade ser complexa, dinâmica e flutuar no tempo em razão dos feitos políticos e reflexões filosóficas, o legislador não trouxe ao ordenamento jurídico atual uma definição ou um conceito hermético para a propriedade, que é verificada através da presença ou não de seus atributos. Ao proprietário é permitido usar, gozar, dispor e reivindicar o bem de quem injustamente o detenha. Estes são os atributos inatos à propriedade que, quando reunidos em determinada situação fática conferem poder jurídico ao titular do domínio para exercer a propriedade de seu bem. Tais elementos caracterizadores se encontram plasmados no caput do art. 1228 do atual Código Civil, abaixo transcrito:

Art. 1.228. O proprietário tem a faculdade de usar, gozar e dispor da coisa, e o direito de reavê-la do poder de quem quer que injustamente a possua ou detenha.

Para tratar do tema propriedade é necessário se debruçar no estudo de uma miríade de doutrinas, ideologias e acepções históricas distintas. Malgrado a dificuldade na conceituação do instituto, a doutrina jurídica vislumbra a propriedade 
•• Tributação, direitos fundamentais e desenvolvimento

como um direito natural9 ${ }^{9}$ isto é, antecedente ao Estado e intrínseco à própria humanidade. Neste diapasão, leciona Caio Mário da Silva Pereira ${ }^{10}$ que a "propriedade mais se sente do que se define, visto que a ideia de "meu" e "teu", a noção do assenhoramento de bens corpóreos e incorpóreos independe do grau de conhecimento ou do desenvolvimento intelectual". Clóvis Beviláqua apresenta a propriedade como "o poder assegurado pelo grupo social à utilização dos bens da vida psíquica e moral"11.

Lafayette $^{12}$ se perde em uma definição não tão precisa a respeito da propriedade, dizendo que "Domínio é o direito real que vincula legalmente e submete ao poder absoluto de nossa vontade a coisa corpórea, na substância, acidentes e acessórios". Ademais, não é um conceito exato, vez que incompatível com o poder de manifestar a vontade, baliza do direito civil.

Modernamente a propriedade se encontra respaldada juridicamente, pois que reconhecida pelo Estado, através de lei, na visão positivista. Neste prisma, se consolida em sua dupla função: de direito subjetivo e de instituto jurídico. Abstraindo-se das explanações teóricas que servem de fulcro para o conceito de propriedade, importa considerar que esta se configura como elemento protagonista dos sistemas jurídicos. Conforme preleciona Francesco Galgano ${ }^{13}$, cada sistema jurídico garante a sua maneira e em suas próprias medidas, a possibilidade de que alguém se aproprie de bens e os utilize em proveito próprio, o que, por conseguinte, exclui a respectiva utilização por terceiros. Para o mencionado autor, que se baseia no Código Civil Italiano, a propriedade é o direito de gozar e dispor de bens, de forma plena e exclusiva.

A propriedade tem por elemento caracterizador a necessidade de inserção temporal e local de sua problemática, isto porque se configura como um direito nota-

9 CARDOSO, Patrícia Silva. Função socioambiental e intervenção do Estado na propriedade: limites e possibilidades à luz da garantia constitucional da propriedade privada. 2016. $348 \mathrm{f}$. (Doutorado em Direito) - Faculdade de Direito, Universidade do Estado do Rio de Janeiro, 2016.

10 PEREIRA, Caio Mário da Silva. Instituiçôes de direito civil. 21. ed. Rio de Janeiro: Forense, 2006, v. IV: Direitos reais, p. 74.

11 BEVILAQUA, Clóvis. Direito das coisas: prefácio de Francisco Cesar Asfor Rocha. Brasília: Imprenta, Senado Federal - Conselho Eiditorial, 2003.

12 PEREIRA, Lafayette Rodrigues. Direito das coisas: prefácio de Sálvio de Figueiredo. Brasília: Imprenta, Senado Federal - Conselho Eiditorial, 2004.

13 GALGANO, Francesco. Diritto privato. 6. ed. Padova: Cedam, 1990, p. 100. 
damente assinalado por uma grande historicidade. O direito de propriedade foi, no decurso do tempo, justificado de maneira dessemelhante, o que positivamente o fez assumir diversas formas - individual, coletiva, fracionada, uniforme, de tal modo que um exame descontextualizado levaria a uma conclusão anacrônica.

Ao estudarmos o instituto e sua evolução história, é possível constatar que sua acepção clássica tem origem no direito romano e até hoje, a qual ainda permanece válida se analisada sob o prisma dogmático. Entretanto, no liberalismo do século XVII, ideologia nascente que impactava sobremaneira na sociedade burguesa então ascendente que este conceito começou a se aperfeiçoar. ${ }^{14}$

A Declaração dos Direitos do Homem e do Cidadão de 1789, legado da Revolução Francesa prezava por um direito de propriedade absoluto através da concepção sacré et inviolable. Seu art. 17 preconizava que:

Art. $17^{\circ}$ Como a propriedade é um direito inviolável e sagrado, ninguém dela pode ser privado, a não ser quando a necessidade pública legalmente comprovada o exigir e sob condição de justa e prévia indenização.

No entanto, novidades são trazidas pela Constituição de Weimar, esta refletindo que a exploração desmedida do bem - outrora faculdade do titular do domínio, era considerada um ilícito. Isto porque era preciso que se compatibilizar a norma jurídica com os anseios de seus destinatários finais os quais tinham necessidades de produção, moradia e consumo a serem satisfeitas. A mensagem da Constituição de Weimar é de sociabilidade, dado que o proprietário não poderia ser árbitro absoluto das escolhas relativas à utilização do bem. Deflui desta premissa o entendimento de que, dentre as muitas posturas possíveis que o proprietário pode tomar, é considerado louvável aquela que é capaz de, sincronicamente, atender os interesses próprios sem se esquecer dos interesses coletivos. ${ }^{15}$

O direito brasileiro não se evadiu de atribuir esta tônica às suas leis. É visto na Constituição de 1934 a reprovação por condutas que sobreponham o uso da propriedade aos interesses coletivos, o que é observado na primeira parte do art. 113, $\$ 17$, conforme trecho abaixo:

14 MENDES, João Augusto Ribeiro. O conceito de propriedade. Dissertação (Mestrado) Universidade Federal de Santa Catarina, Centro de Ciências Jurídicas. Florianópolis, 1994, p. 4.

15 OBERTO, Paula Baptista. Direito agrário: função social da propriedade; sua evolução e história. Disponível em: <http://www.iuspedia.com.br> Acesso em: 9 out. 2017. 
•• Tributação, direitos fundamentais e desenvolvimento

Art. 113. A Constituição assegura a brasileiros e a estrangeiros residentes no País a inviolabilidade dos direitos concernentes à liberdade, à subsistência, à segurança individual e à propriedade, nos termos seguintes:

$\$ 17$ É garantido o direito de propriedade, que não poderá ser exercido contra o interesse social ou coletivo, na forma que a lei determinar.

Já a Constituição de 1946 outorgou ao legislador no art. 147 competência para que os Estados e Municípios pudessem desapropriar bens desde que houvesse nesta medida interesse social, promovendo, assim, o justo reparto da propriedade. Para tanto foi editada a Lei n. 4.132, de 10-09-62 e posteriormente, a Emenda Constitucional 10, de 09-11-64, que foi mais além instituindo a possibilidade de desapropriação por interesse social como forma de sancionar o proprietário remisso a adequar a utilização dos imóveis rurais a sua função social, procedendo-se ao pagamento da indenização mediante títulos especiais da dívida pública. Referida modalidade expropriatória, com algumas variantes, foi mantida pela Constituição de 1967 (art. 157, $\$ \$ 1^{\circ}$ a $6^{\circ}$ ) e pela Emenda Constituição 01/69 (art. 161, $\$ \$ 1^{\circ}$ a $\left.5^{\circ}\right) \cdot{ }^{16}$

Todavia, esta nuance não foi refletida no Código Civil de 1916 o qual não impunha quaisquer restrições ao exercício do direito de propriedade, pois o proprietário era considerado senhor de sua coisa e a ela poderia destinar o tratamento que julgasse apropriado.

Com o decorrer dos anos e diante de dos anseios sociais que surgiam pugnando por uma distribuição de riquezas que se operasse de maneira mais justa e, ainda, em razão da necessidade de intervenção estatal em tal demanda foi que o caráter absoluto e inviolável do direito de propriedade se esvaiu para abrir espaço à sua relativização trazida pelo Código Civil de 2002.

$\mathrm{O}$ atual Código carrega consigo uma acepção de propriedade que não se desvincula dos compromissos econômicos e sociais que o proprietário deve ter em relação ao bem. O direito de propriedade sob o prisma hodierno refletido em nosso diploma legal é condicionado ao cumprimento de sua função social. Isto porque a Carta Maior especificou nos incisos XXII e XXIII de seu art. $5^{\circ}$ acerca da indispensabilidade do exercício do jus proprietatis, que sempre obedecerá à missão social, senão vejamos:

A POSSE e a propriedade no novo Código Civil. Disponível em: <http://www.buscalegis. ufsc.br/revistas/files/anexos/7992-7990-1>-PB.htm. Acesso em: 23 set. 2017. 
Art. 50 Todos são iguais perante a lei, sem distinção de qualquer natureza, garantindo-se aos brasileiros e aos estrangeiros residentes no País a inviolabilidade do direito à vida, à liberdade, à igualdade, à segurança e à propriedade, nos termos seguintes:

XXII - é garantido o direito de propriedade;

XXIII - a propriedade atenderá a sua função social;

Em virtude da disposição constitucional toda a legislação precisou ser amoldada para se tornar consentânea à Constituição Federal, vez que restou comprovada a adoção do princípio da função social por todo o ordenamento jurídico. Ensina o art. 1228 do Código Civil de 2002, litteris:

Art. 1.228. (...)

$\$ 1^{\circ} \mathrm{O}$ direito de propriedade deve ser exercido em consonância com as suas finalidades econômicas e sociais e de modo que sejam preservados, de conformidade com o estabelecido em lei especial, a flora, a fauna, as belezas naturais, o equilíbrio ecológico e o patrimônio histórico e artístico, bem como evitada a poluição do ar e das águas. (Grifos nossos).

(...)

$\$ 2^{\circ}$ São defesos os atos que não trazem ao proprietário qualquer comodidade, ou utilidade, e sejam animados pela intenção de prejudicar outrem.

Nota-se que o $\$ 1^{\circ}$ retromencionado traz à baila mais uma condicionante do direito de propriedade, qual seja, o respeito ao meio ambiente equilibrado - direito fundamental consagrado no art. 225 da Carta Magna. É de suma importância a previsão do dispositivo para que seja possível abarcar os direitos fundamentais de terceira geração. ${ }^{17}$

17 De acordo com Paulo Bonavides os direitos de terceira geração "são aqueles dotados de altíssimo teor de humanismo e universalidade, os direitos da terceira geração tendem a cristalizar-se no fim do século XX enquanto direitos que não se destinam especificamente à proteção dos interesses de um indivíduo, de um grupo ou de um determinado Estado. Tem primeiro por destinatário o gênero humano mesmo, num momento expressivo de sua afirmação como valor supremo em termos de existencialidade concreta.” A concepção constitucional de meio ambiente reconhece a necessidade de harmonia entre os seres sociais e sua convivência no meio em que estão inseridos. Pode-se dizer que há na garantia constitucional um caráter metaindividual (característico dos direitos fundamentais de $3^{\text {a }}$ geração), de modo que os direitos das gerações futuras também são alvo de proteção - por meio da sustentabilidade. Neste diapasão, a Conferência de Esotcolmo de 1972 preconiza: "O homem é ao mesmo tempo criatura e criador do meio ambiente, que lhe dá sustento físico e lhe oferece a oportunidade de desenvolver-se intelectual, moral, social e espiritualmente. A longa e difícil evolução da raça humana no planeta levou-a a um estágio em que, com o rápido progresso da Ciência e da Tecnologia, conquistou o poder de transformar de inúmeras maneiras e em escala sem precedentes o meio ambiente. 
•• Tributação, direitos fundamentais e desenvolvimento

Consectário do reconhecimento da função social da propriedade o $\$ 2^{\circ}$, além das limitações tradicionais inerentes ao direito de vizinhança constantes nos artigos 1277 a 1313, o atual Código estatuiu a proibição de atos eivados de intenção do proprietário em prejudicar terceiros. Este enunciado hauriu arrimo no art. 833 do Código Civil da Itália que no que tange aos atos emulativos disciplina: "O proprietário não pode praticar atos que não tenham outro escopo senão aquele de lesar ou trazer moléstia a outrem.” ${ }^{18}$ O Código Civil de 2002, diversamente do Código de 1916, optou por reduzir os vocábulos "domínio" e "propriedade" a sinônimos. No antigo diploma, ambos guardavam diferentes significados ${ }^{19}$, embora hoje sejam usados com igual consideração.

Assim, a transição do significado de propriedade - de direito exercido pelo sujeito sobre a coisa, a relação jurídica com complexidades e pormenores, relativizou sua essência e quebrou a estrutura asséptica e formal de uma sociedade estagnada. Dona de contornos atualmente funcionalizados, a propriedade tem por balizas a supremacia dos valores de solidariedade e igualdade, estes sempre interpretados conforme a Constituição Federal.

\subsection{Atributos da propriedade}

É curial apontar que a propriedade, apesar de definida pelos seus atributos, não é atada ao Código Civil, pois assume diversos perfis de acordo com as transmutações inclusive sociais que o ambiente experimenta. A respeito de tal máxima comentam os mestres Cristiano Chaves de Farias e Nelson Rosenvald ${ }^{20}$ nos seguin-

Natural ou criado pelo homem, é o meio ambiente essencial para o bem-estar e para gozo dos direitos humanos fundamentais, até mesmo o direito à própria vida.

18 No original: Il proprietario non può fare atti i quali non abbiano altro scopo che quello di nuocere o recare molestia ad altri”.

19 Entende-se domínio como a ingerência direta sobre o bem, não havendo que se falar em obrigaçōes ou em terceiros. Recai o domínio unicamente sobre o campo dos direitos reais. É sabido que, em tendo o domínio, tem o proprietário as faculdades de usar, gozar, dispor e reivindicar. Contudo, a propriedade tem um conceito muito mais expandido, indo além da equação "usar, dispor, reivindicar e gozar". Ter a propriedade significa ter a titularidade do bem, enquanto ter o domínio é ter a submissão da propriedade em seu conteúdo. Um se dá em decorrência do outro. Deste modo, é sentida certa atecnia do legislador do Código Civil de 2002 ao reduzir as diferentes terminologias a sinônimos, porquanto um instituto guarde maior amplitude do que outro.

20 FARIAS, Cristiano Chaves de; ROSENVALD, Nelson. Curso de direito civil. 12. ed. conforme Novo CPC. Rio de Janeiro: Juspodivm, 2016, v. V: Reais, p. 269. 
tes termos: "O sistema de direito civil não é refém do Código Civil. Com ele, convivem microssistemas de propriedades, que retratam todos os impactos da ordem econômica e social no fenômeno da propriedade". Leciona, ainda, a respeito Francisco Loureiro ${ }^{21}$ que "Houve uma transformação do direito de propriedade em poder econômico sobre o mercado. Em outras palavras a propriedade passou de poder sobre coisas a poder de comando". Desta feita, é consenso que é inerente ao indivíduo a apropriação de bens como forma de concretização de seus próprios interesses.

É em virtude desta elasticidade contida no conceito de propriedade, isto é, da capacidade deste direito se transfigurar que a Constituição Federal visa a cingir os vários tipos de relações que se desenvolvem no entorno da propriedade, compreendendo a propriedade pública, privada, empresarial, urbana, rural, e delineando uma diretriz mínima para exploração econômica do bem. Por conseguinte, o conjunto "usar, gozar, dispor, reivindicar" deverá ser diversamente interpretado de acordo com a propriedade in casu. Cumpre destacar que os atributos da propriedade não se perdem pelo seu não uso. São faculdades concedidas ao proprietário, isto é, tem o proprietário a aptidão, o poder ou capacidade para exercê-los, a liberdade de agir, o que não se confunde com imposiçôes ou obrigações predeterminadas pelo ordenamento para que se veja caracterizada a propriedade.

Para que se esclareça qual é a relação existente entre a função social da propriedade a sua tributação, é necessário compreender que, de modo geral, os poderes estatais constituem uma decorrência da soberania, um dos elementos caracterizadores para a formação de um Estado. As relações de poder entre o Estado e os particulares sinalizam a posição de independência e supremacia daquele sobre estes. Nas palavras de Hans Kelsen "A afirmação de que a soberania é uma qualidade essencial do Estado significa que o Estado é uma autoridade suprema. A "autoridade" costuma ser definida como o direito ou poder de emitir comandos obrigatórios. O poder efetivo de forçar os outros a certa conduta não basta para constituir uma autoridade" ${ }^{22}$ A soberania, em outras palavras, é a capacidade jurídica e territorial de autodeterminação, fixando competências dentro do território estatal e limitando a invasão de outro Estado.

21 LOUREIRO, Francisco Eduardo. A propriedade como relação jurídica complexa. Rio de Janeiro: Renovar, 2003, p. 57-58.

22 KELSEN, Hans. Teoria geral do direito e do estado. Tradução de Luis Carlos Borges. 3. ed. São Paulo: Martins Fontes, 2000, p. 544. 
-. Tributação, direitos fundamentais e desenvolvimento

Todavia, uma exegese mais moderna aponta que o poder não enseja exatamente uma relação de força do Estado sobre os indivíduos. A Administração Pública orienta-se pelos princípios da supremacia e indisponibilidade do interesse público os quais privilegiam o bem comum em detrimento dos interesses individuais, razão pela qual é justificada a privilegiada posição estatal.

A implicação direta disso é que, em certos momentos, alguns interesses particulares precisarão ser sacrificados em prol do bem estar social. Da soberania estatal aliada aos referidos princípios extrai-se a legitimidade do poder de tributar, que uma vez configurada faz nascer a necessidade de enquadrar o tributo nesse contexto, o que não se mostra uma tarefa complexa em razão do silogismo de que se o poder de tributar se presta a atender às preocupações grupais, por consequência, o mesmo se dá com relação ao tributo.

A respeito do termo "função", aponta brilhantemente Celso Antônio Bandeira de Mello que "existe função quando alguém está investido no dever de satisfazer dadas finalidades em prol do interesse de outrem: a coletividade" ${ }^{23}$. Assim, torna-se possível afirmar que o tributo tem por função social a colaboração com o bem estar da sociedade; Esta é uma ideia que se liga intimamente à de justiça tributária e distributividade.

A função social do tributo encontra arrimo na Constituição Federal que em seu artigo $3^{\circ}$ determina os objetivos da República Federativa do Brasil, nos seguintes termos:

Art. $3^{\circ}$ Constituem objetivos fundamentais da República Federativa do Brasil:

I - construir uma sociedade livre, justa e solidária;

II - garantir o desenvolvimento nacional;

III- erradicar a pobreza e a marginalização e reduzir as desigualdades sociais e regionais;

IV- promover o bem de todos sem preconceitos de origem, raça, sexo, cor, idade e quaisquer outras formas de discriminação.

Por conseguinte, a justiça social, no sentido de oferecer benefícios indistintamente a todos e custear os direitos sociais constitucionalmente previstos apenas é possível de ser concretizada se contar com a arrecadação das exações impostas aos particulares. Mediante a correta aplicação das receitas públicas é possível promover o desenvolvimento nacional.

BANDEIRA DE MELLO, Celso Antônio. Curso de direito administrativo. 22. ed. São Paulo: Malheiros, 2007, p. 68. 
Essa compreensão conduz ao vislumbre de diversas nuances do instituto da função social, que possibilitam novos patamares de reflexão. Por certo o tributo é a via pela qual se concretiza a participação social no bem comum - objetivo previsto no supracitado artigo $3^{\circ}$ da Carta da República como solidariedade. Se por um lado o particular tem o dever de pagar o tributo, o Estado, em contrapartida, tem o dever de empregar o que arrecada em benefícios coletivos.

A solidariedade e a propriedade são princípios justificadores da tributação. $\mathrm{O}$ tributo é capaz de estimular a realização da função social da propriedade e de limitar a sua utilização sem que ofenda o direito constitucional do direito à propriedade, na medida em que o tributo se forma para garantir a solidariedade, expropriando-se parte do patrimônio dos indivíduos em prol das necessidades públicas.

Conforme Regina Helena Costa ${ }^{24}$, o direito urbanístico "compreende o conjunto de normas jurídicas reguladoras da atividade do Poder Público destinado a ordenar espaços habitáveis" e, vale lembrar, que o princípio que informa o direito urbanístico é o da função social da propriedade. Neste diapasão, a autora afirma, ainda, que a intersecção entre o direito urbanístico e direito tributário é a extrafiscalidade.

A extrafiscalidade, segundo Geraldo Ataliba ${ }^{25}$, consiste em uma forma não arrecadatória de tributar, uma vez que sua finalidade não visa à geração de recursos para o Estado, mas estimular, induzir ou inibir comportamentos, tendo em vista a realização de valores consagrados pela Constituição. É desta maneira que a tributação se revela um instrumento eficaz para persecução de finalidades sociais e promoção de políticas urbanas, e, por conseguinte, para realizar a função social da propriedade.

Exemplo que comprova o entendimento acima explanado é a progressividade das alíquotas do Imposto sobre a Propriedade Predial e Territorial Urbana - IPTU. Esta progressividade possui um caráter dúplice, posto que assume feição da chamada progressividade simples ou ainda da progressividade no tempo. A primeira consiste na adoção de alíquotas variáveis proporcionais à base de cálculo do imposto encontra previsão constitucional nos arts. $153, \$ 4^{\circ}$, II e $156, \$ 1^{\circ}$, enquanto a segunda é

24 COSTA, Regina Helena. Instrumentos tributários para implementação da política urbana (art. 7o). In: DALLARI, Adilson Abreu; FERRAZ, Sérgio (Coord.). Estatuto da cidade: comentários à lei federal 10.257/01. São Paulo: Malheiros, 2003, p. 102.

25 ATALIBA, Geraldo. Hipótese de incidência tributária. 6. ed. São Paulo: Malheiros, 2006. 
•• Tributação, direitos fundamentais e desenvolvimento

caracterizada pelo uso de alíquotas crescentes com o passar do tempo e está prevista no art. $182, \$ 4^{\circ}$, II, da Constituição Federal. De acordo com esta progressividade, em não sendo dada destinação ao bem imóvel cuja propriedade é tributada, o imposto passará a ter alíquotas mais gravosas.

Assim, o IPTU ganhou com a atual Constituição um papel de destaque na implementação da política urbana, ao passo que pode ser utilizado para estimular os proprietários a cumprir o estabelecido no Plano Diretor do Município e, destarte, garantir o atendimento da função social da propriedade. O legislador utilizou a tributação como ferramenta de política estatal, prática que se revela altamente eficaz, pois atinge o indivíduo em um de seus pontos mais vulneráveis - suas finanças.

Neste deslinde ocorre a desmistificação do tributo apenas como meio de angariar receitas a serem injetadas na máquina pública é de suma importância para que o fenômeno da tributação não seja visto pela sociedade apenas pelo prisma da dominação ou da espoliação, mas como via de atendimentos dos efeitos buscados pela Administração, estes inseridos em uma visão macro da política econômica.

\subsection{Transferência da propriedade imobiliária e sua tributação: uma limitação ao direito de propriedade?}

Seguindo a ideia do subitem anterior, qual seja, o uso do tributo como instrumento de política social, é questionável o alcance da tributação da transferência da propriedade imobiliária. Assim, em se tratando de Imposto sobre Transmissão de Bens Imóveis, tributo estudado no presente trabalho, cumpre analisar se este se trata de uma exação que fere o direito de propriedade plasmado na Constituição Federal. Por tal razão, vale a realização de um breve escorço histórico dos sistemas de transferências de bens até o momento corrente.

Os direitos reais e obrigacionais guardam distinções inclusive em seu modo de aquisição. Os direitos reais possuem modos de aquisição previamente consubstanciados na lei. Muitos foram os sistemas de transferências de bens imóveis ao longo do tempo. Conforme ensinamento de Eugênio Klein Dutra ${ }^{26}$, o mais antigo é o sistema de Roma, advindo do chamado Antigo Testamento judaico, que continha

DUTRA, Eugênio Klein. Sistemas de transferência da propriedade imóvel. Disponível em: $<$ http://domtotal.com/direito/pagina/detalhe/33189/sistemas-de-transferencia-da-propriedade-imovel>. Acesso em: 20 set. 2017. 
as 10 Tábuas da Lei, porque foi encampado pelo Direito Justinianeu, qual seja, a codificação do Direito - Corpus Juris Civilis elaborada durante o reinado do Imperador Justiniano. A codificação enfatizava a tradição solene, baseada no brocardo traditionibus, non nudis pactis, dominia rerum transferuntur, que diz: pela tradição e não por simples contrato transfere-se o dominio das coisas. O mais antigo exemplo que contém os requisitos ainda hoje indispensáveis a uma escritura pública legítima, é a passagem bíblica de Abraão adquirindo uma sepultura para sua mulher, Sarah, no qual havia identificação das partes, na presença de testemunhas perante um tabeliāo em local público. ${ }^{27}$

Contou-se também com o sistema francês, este instituído pelo código napoleônico e adotado em quase toda a Europa. Tal sistema primou pela simplificação do procedimento, no qual a transferência da propriedade decorria do próprio contrato ou da escritura; vem dessa época o costume de se consignar que a transferência do domínio, posse, direito e ação se davam por força da escritura, esta se configurando como elemento probatório do domínio. ${ }^{28}$

Finalmente surgiu o "sistema germânico". Na Alemanha era permitido que a escritura fosse lavrada em qualquer lugar, o que dificultava a obtenção de dados seguros acerca do domínio dos imóveis ou da existência de possíveis ônus que gravavam os bens. Por esta razão, foi instituído o registro imobiliário, que era realizado sempre no foro de situação da coisa. O registro era destinado a operar a transferência do domínio e a tornar os ônus que gravavam o imóvel oponíveis a terceiros - assegurando sua publicidade. O elemento probatório passou a ser a certidão do registro da escritura. ${ }^{29}$

Na codificação do Direito Civil brasileiro, o Código Civil de 1916 compatibilizou os sistemas francês e alemão. O direito pessoal decorre da escritura pública, de caráter obrigatório, sendo esta a substância do ato. Já o direito real - a transferência do domínio - fica condicionado ao registro dessa escritura no Registro Imobiliário competente. Desta forma, o Código Civil insere na categoria dos registros públicos o REGISTRO DE IMÓVEIS, este com o fito de materializar a transmissão da propriedade imobiliária e de garantir a oponibilidade erga omnes dos direitos reais.

\footnotetext{
Idem.
}

28 Idem.

29 Idem. 
•• Tributação, direitos fundamentais e desenvolvimento

A princípio, os direitos e os bens circulam entre as pessoas pela via do contrato. $\mathrm{O}$ contrato é o instrumento que possui o condão de firmar a responsabilidade assumida em uma transação a fim de produzir os efeitos obrigacionais decorrentes do negócio celebrado. Todavia, tais efeitos são considerados res inter alios acta, isto é, são válidos exclusivamente entre quem os celebra, não alcançando terceiros. Ocorre que, apesar do contrato consistir em um instrumento regido pela liberdade negocial e autonomia da vontade, deve haver segurança na transferência do patrimônio no sentido de proteger os interesses de terceiros para que não se perca a estabilidade negocial.

Neste sentido preleciona Francisco Landim ${ }^{30}$ que o contrato deverá respeitar

Sua função econômica de promover a circulação e riquezas por ato do próprio dono da coisa (liberdade), com a devida visibilidade para terceiros (aparência), e a necessidade de segurança jurídica para o adquirente do bem circulante (segurança da circulação). Harmonizam-se com estas providências os interesses de cada uma das partes e de terceiros na transferência de propriedade.

Quando é lavrada uma escritura de compra e venda de bem imóvel, o beneficiário adquire um título, isto é, se torna credor de uma obrigação de dar - prevista no art. 237 do Código Civil, porém, ainda não ostenta o status de proprietário. Para que se perfaça a obrigação o negócio jurídico deve ser depositado junto ao Registro Geral de Imóveis a fim de que se transfira de fato a propriedade do bem, vez que o art. 1245 do referido diploma civilístico, in verbis

Art. 1.245. Transfere-se entre vivos a propriedade mediante o registro do título translativo no Registro de Imóveis. (Grifos nossos).

$\$ 1^{\circ}$ Enquanto não se registrar o título translativo, o alienante continua a ser havido como dono do imóvel.

$\$ 2^{\circ}$ Enquanto não se promover, por meio de ação própria, a decretação de invalidade do registro, e o respectivo cancelamento, o adquirente continua a ser havido como dono do imóvel.

Desta forma, o registro pode ser considerado como garantia do direito da propriedade particular, pois é uma atividade instrumental com vistas a satisfazer o exercício pleno da propriedade privada e, sobretudo, da segurança jurídica. Afinal, para que recursos sejam atraídos e para que haja bem estar social, o direito de propriedade deve estar encampado em uma posição segura, com contornos nitidamen-

30 LANDIM, Francisco. A propriedade imóvel na teoria da aparência. São Paulo: CD Livraria e Editora, 2001, p. 33. 
te delineados. É necessária a existência de um instrumento capaz de delimitar o que pertence a quem, função precípua do registro.

Portanto, tanto a progressividade tratada no item anterior, como a tributação incidente na transferência imobiliária devem ser implementadas em estrita consonância aos ditames constitucionais, sob pena de incorrerem em violação ao princípio da vedação de tributo com efeito de confisco, insculpido no art. 150, IV da Lei Maior. Este princípio determina que não pode haver cobranças que acarretem a perda substancial ou total do patrimônio do contribuinte, de forma que o valor da exação deve respeitar a capacidade contributiva destes, isto porque configura-se como uma limitação ao poder de tributar do Estado que, por conseguinte, oferece uma garantia fundamental ao sujeito passivo.

\section{A ÂNSIA ARRECADATÓRIA DOS MUNICÍPIOS E SUA MANIFESTA INCONSTITUCIONALIDADE}

Inobstante a importância do combate à evasão e sonegação fiscal, não se pode acreditar que esta contenda deva se dar de modo absoluto e irrestrito, porquanto não guardam relação com o Estado Democrático de Direito premissas absolutas e irrestritas, e, para tanto é que a Carta da República brinda o ordenamento jurídico com princípios os quais não são de nenhuma forma engessados, mas afiguram-se como norteadores e encaminhadores, além de possibilitarem respiração no momento de interpretar os dispositivos legais.

Diz-se isto, pois, em razão do anseio de determinados municípios por evitar o não pagamento do ITBI, estes se equivocam em suas leis orgânicas ao disciplinarem o momento de recolhimento do tributo de forma antecipada. Assim, legislam caracterizando o momento de ocorrência de uma das hipóteses de incidência do ITBI diversamente de sua previsão legal, a qual se encontra no artigo 35 do Código Tributário Nacional, in verbis:

Art. 35. O imposto, de competência dos Estados, sobre a transmissão de bens imóveis e de direitos a eles relativos tem como fato gerador:

I - a transmissão, a qualquer título, da propriedade ou do domínio útil de bens imóveis por natureza ou por acessão física, como definidos na lei civil; (grifos nossos) II - a transmissão, a qualquer título, de direitos reais sobre imóveis, exceto os direitos reais de garantia;

III - a cessão de direitos relativos às transmissões referidas nos incisos I e II. Parágrafo único. Nas transmissões causa mortis, ocorrem tantos fatos geradores distintos quantos sejam os herdeiros ou legatários. 
•• Tributação, direitos fundamentais e desenvolvimento

Ademais, a Carta de República ao outorgar aos municípios o poder de instituir os impostos de sua competência o faz com a devida intelecção e não causa dúvida quanto ao momento em que se perfaz no mundo concreto a hipótese descrita, qual seja, a transferência de propriedade. A previsão constitucional reside no inciso II do art. 156, senão vejamos:

Art. 156. Compete aos Municípios instituir impostos sobre: (...)

II - transmissão “inter vivos”, a qualquer título, por ato oneroso, de bens imóveis, por natureza ou acessão física, e de direitos reais sobre imóveis, exceto os de garantia, bem como cessão de direitos a sua aquisição; (grifos nossos)

Neste dispositivo a CRFB carrega a hipótese de incidência do ITBI, e, se combinados o preceito constitucional com a hipótese prevista no Código Tributário Nacional, por certo a interpretação resultante não deve dar azo à dúvidas ou erros acerca do critério material da regra matriz de incidência do imposto aqui tratado. Isto porque malgrado os dispositivos transcritos não apresentem o conceito de “transmissão de bem imóvel” o Código Civil o faz no caput de seu art. 1245 nos seguintes termos:

Art. 1.245. Transfere-se entre vivos a propriedade mediante o registro do título translativo no Registro de Imóveis.

$\$ 1^{\circ}$ Enquanto não se registrar o título translativo, o alienante continua a ser havido como dono do imóvel.

$\$ 2^{\circ}$ Enquanto não se promover, por meio de ação própria, a decretação de invalidade do registro, e o respectivo cancelamento, o adquirente continua a ser havido como dono do imóvel. (Grifos nossos).

Contudo, em razão da competência municipal para instituição do tributo ora estudado, algumas leis orgânicas disciplinam como devido o Imposto sobre Transmissão de Bens Imóveis Inter Vivos antes de verificado no mundo prático o fato imponível, exempli gratia, a incidência de ITBI nos compromissos de compra e venda. $\mathrm{O}$ contrato de promessa de compra e venda não tem o condão de transferir a titularidade do bem imóvel ao promitente- comprador, porquanto não efetiva o registro da escritura de compra e venda na matrícula do imóvel. Sem a escrituração não há transferência de propriedade.

A promessa de compra e venda consiste em espécie contratual por intermédio da qual uma pessoa, física ou jurídica, denominada promitente ou compromitente vendedora, assume a obrigação de vender a outra, denominada promissária ou compromissária (ou promitente) compradora, bem imóvel por preço, condições e 
modos previamente pactuados. Na preleção de Orlando Gomes, "Ao celebrá-lo, [as partes] não visariam modificar diretamente sua efetiva situação, mas, apenas, a criar a obrigação de um futuro contrato" ${ }^{31}$. Nos dizeres do mestre Caio Mário da Silva Pereira: "Originariamente a promessa de compra e venda há de ser um pré-contrato, que, como toda avença desta espécie, tem por objeto a celebração de outro, que será então o contrato definitivo"32. Francisco Muniz, dotado de muita didática, referindo-se ao contrato de compra e venda afirma que

pelo contrato de promessa de compra e venda, uma das partes se obriga a comprar e a outra se obriga a vender. As partes se obrigam a celebrar o contrato definitivo. A promessa gera, pois, uma obrigação de contratar: emitir uma declaração de vontade de acordo com o contrato prometido. ${ }^{33}$

Neste sentido, o Supremo Tribunal Federal firmou entendimento no sentido de afastar a incidência do ITBI dos contratos de promessa de compra e venda, na observância do da não ocorrência do fato jurídico tributário do referido imposto em tais situações, senão vejamos os seguintes precedentes:

AGRAVO REGIMENTAL EM RECURSO EXTRAORDINÁRIO COM AGRAVO. DIREITO TRIBUTÁRIO. DIREITO PROCESSUAL CIVIL. DEVIDO PROCESSO LEGAL. ITBI. FATO GERADOR. PROMESSA DE COMPRA E VENDA. 1. A jurisprudência do STF se consolidou no sentido de que suposta ofensa aos princípios do devido processo legal, da ampla defesa, do contraditório e dos limites da coisa julgada, quando a violação é debatida sob a ótica infraconstitucional, não apresenta repercussão geral. Precedente: RE-RG 748.371, de relatoria do Ministro Gilmar Mendes, DJe 10.8.2013. 2. A transferência do domínio sobre o bem torna-se eficaz a partir do registro público, momento em que incide o Imposto Sobre Transferência de Bens Imóveis (ITBI), de acordo com a jurisprudência do Supremo Tribunal Federal. Logo, a promessa de compra e venda náo representa fato gerador idôneo para propiciar o surgimento de obrigação tributária. 3 . Agravo regimental a que se nega provimento. (Grifos nossos).. ${ }^{34}$

AGRAVO REGIMENTAL EM RECURSO EXTRAORDINÁRIO COM AGRAVO. IMPOSTO SOBRETRANSMISSĀO DE BENS IMÓVEIS. FATO GERADOR

31 GOMES, Orlando. Direitos reais. 9. ed. Rio de Janeiro: Forense, 1985, p. 318. Registra-se que Orlando Gomes entende que a promessa de compra e venda, por sua eficácia real, não pode ser considerada espécie de contrato preliminar, mas contrato típico.

32 PEREIRA, Caio Mário da Silva. Op. cit., p. 446.

33 MUNIZ, Francisco José Ferreira. Embargos de terceiros à penhora. A questão da posse do promitente comprador. In: Textos de Direito Civil. Curitiba: Juruá, 1998, p. 121.

34 BRASIL. Supremo Tribunal Federal. ARE 807.255 AgR/RJ. Publicação DJe 03/11/2015. Rel.: Min. Edson Fachin, 
•• Tributação, direitos fundamentais e desenvolvimento

PROMESSA DE COMPRA E VENDA. IMPOSSIBILIDADE. A obrigação tributária surge a partir da verificação de ocorrência da situação fática prevista na legislaçáo tributária, a qual, no caso dos autos, deriva da transmissão da propriedade imóvel. Nos termos da legislação civil, a transferência do domínio sobre o bem torna-se eficaz a partir do registro. Assim, pretender a cobrança do ITBI sobre a celebração de contrato de promessa de compra e venda implica considerar constituído o crédito antes da ocorrência do fato imponível. Agravo regimental a que se nega provimento" (grifos nossos). ${ }^{35}$

"PROCESSUAL CIVIL. AGRAVO REGIMENTAL NO RECURSO EXTRAORDINÁRIO COM AGRAVO. PRELIMINAR DE REPERCUSSÃO GERAL. FUNDAMENTAÇÃO DEFICIENTE. ÔNUS DO RECORRENTE. AUSÊNCIA DE PREQUESTIONAMENTO. SÚMULAS 282 E 356 DO STF. TRIBUTÁRIO. ITBI. CONTRATOS DE PROMESSA DE COMPRA E VENDA. COBRANÇA INDEVIDA. PRECEDENTES. AGRAVO REGIMENTAL A QUE SE NEGA PROVIMENTO"36 (grifos nossos).

Incontáveis municípios ${ }^{37}$ na ânsia de arrecadar o tributo praticam uma conduta abusiva ao preverem em suas leis orgânicas a sua cobrança antes de ocorrido o fato gerador. Isto se dá em virtude de uma equivocada presunção de capacidade contributiva daqueles que realizaram o negócio jurídico da promessa de compra e venda a qual pode no futuro não se concretizar, conforme hipótese em que restará para o promitente comprador buscar na seara cível a reparação de seu prejuízo, haja vista serem inoponíveis à esfera tributária os contratos particulares, conforme estabelecido no artigo 123 do CTN, in verbis

35 BRASIL. Supremo Tribunal Federal. Agravo Regimental em Recurso Extraordinário com Agravo 805859/RJ. Publicação DJe 09/03/2015. Rel. Min. Luis Roberto Barroso.

36 BRASIL. Supremo Tribunal Federal. ARE 798.004/RJ. Publicação DJe 07/052014. Rel. Min. Teori Zavascki.

37 Vide legislações de determinados municípios como o Rio de Janeiro, que dispõe no art. 20 da lei municipal 1348/88 "O promitente comprador e o promitente cessionário, na hipótese de haver quitação contratual, ficam obrigados a apresentar à repartição fazendária o respectivo título, acompanhado da prova de pagamento do imposto, efetuado na forma do caput deste artigo, no prazo de 30 (trinta) dias, a contar da data prevista no instrumento para o efetivo pagamento total do preço, sob pena de aplicação da multa prevista no art. 23, inciso IV desta lei, sem prejuízo das demais penalidades cabíveis”. Em 1984 foi julgada a Representação de Inconstitucionalidade 1121-6/GO, a qual abriu precedentes para os julgados posteriores por considerar inconstitucional o inciso I do parágrafo único do artigo 114 da Lei n. 7.730, de 30 de outubro de 1973, do Estado de Goiás (à época, o imposto era de competência estadual), que dispunha ser legítima a cobrança do ITBI nos compromissos de compra e venda. Ademais, conforme tópico apropriado a seguir, o município de Uberlândia também teve declarada a inconstitucionalidade dos dispositivos de lei municipal que impunham o pagamento da exação em estudo nos momentos anteriores à ocorrência do respectivo fato gerador. 
Art. 123. Salvo disposições de lei em contrário, as convenções particulares, relativas à responsabilidade pelo pagamento de tributos, não podem ser opostas à Fazenda Pública, para modificar a definiçãao legal do sujeito passivo das obrigações tributárias correspondentes.

Dada a inconstitucionalidade da cobrança, os tribunais superiores já têm pacificado que a propriedade imobiliária transmite-se exclusivamente com o respectivo registro no Cartório de Registro de Imóveis competente, conforme já explicitado no presente trabalho. Contudo, não era o firmado nas decisões antigas, a exemplo do Recurso Extraordinário n. 75.124-DF, de 1981. À época, o entendimento consolidado definia o negócio jurídico como fato gerador da transmissão do imóvel. Ao votar o recurso, o Relator cita Aliomar Baleeiro na 9a edição de sua obra "Direito Tributário Nacional", que descrevia o fato gerador do imposto de transmissão de bens imóveis na seguinte inteligência:

Juridicamente, tem por fato imponível, ou "fato gerador" da obrigação fiscal, a transferência de domínio, isto é, o contrato de compra e venda, a doação, o ato da arrematação etc., a transmissão por óbito - e não a transcrição do instrumento no registro público. ${ }^{38}$

No entanto, é mister lembrar que nessa ocasião o imposto ainda estava sob a competência estadual e incidia sobre bens transmitidos causa mortis e por ato oneroso.

Ementa: 1. O SUPREMO TRIBUNAL FEDERAL FIRMOU O ENTENDIMENTO DE QUE O IMPOSTO DE TRANSMISSÃO DE BEM IMÓVEL DEVE SER PAGO NA CONSIDERAÇÃO DO VALOR QUE TENHA O IMÓVEL NO MOMENTO DO NEGÓCIO JURÍDICO PELO QUAL FOI ELE TRANSFERIDO.

2. SÚMULA, VERBETE 108 PRECEDENTE DA CORTE. RECURSO EXTRAORDINÁRIO DO FISCO LOCAL A QUE SE DÁ PROVIMENTO. ${ }^{39}$

No voto do presente Recurso, o Relator aponta o fato gerador do tributo como sendo o negócio jurídico. A seguir, é citada a súmula 108, de 13/12/1963, que pacifica a divergência quanto ao elemento quantitativo do fato gerador: se o valor do imóvel à época da promessa de compra e venda ou se no momento da lavratura da escritura definitiva, nos seguintes termos: "É legítima a incidência do imposto de transmissão inter vivos sobre o valor do imóvel ao tempo da alienação, e não da promessa, na conformidade da legislação local”.

38 BALEEIRO, 2010 apud RE 75124.

39 BRASIL. Supremo Tribunal Federal. Recurso Extraordinário 75124/DF. Publicação DJe 04/05/1981. Rel. Min. Antonio Neder. 
-. Tributação, direitos fundamentais e desenvolvimento

Nos dizeres de Nogueira ${ }^{40}$, se a base de cálculo do ITBI deve ser o valor do imóvel ao tempo da alienação, depreende-se da Súmula 108 que o fato gerador do ITBI considera-se ocorrido com a celebração do contrato de compra e venda. Caso o fato gerador ocorresse apenas no registro do imóvel, a base de cálculo seria o valor do imóvel naquele momento.

Apesar dos Tribunais não mais demonstrarem divergência no que tange ao momento da ocorrência do fato gerador do imposto sobre transmissão, a Súmula 108 continua sendo utilizada. O Recurso Especial abaixo teve seu acórdão produzido já sob a égide da Constituição atual. É este o sentido para o qual rumam os acórdãos dos Tribunais, que não têm entendimento contrário à ocorrência do fato gerador do ITBI no momento do registro imobiliário, caracterizando-o como único momento possuidor do condão de transferir a propriedade do imóvel.

TRIBUTÁRIO - IMPOSTO DE TRANSMISSÃO DE BENS IMÓVEIS FATO GERADOR - REGISTRO IMOBILIÁRIO - (C. CIVIL, ART. 530). A PROPRIEDADE IMOBILIÁRIA APENAS SE TRANSFERE COM O REGISTRO DO RESPECTIVO TÍTULO (C.CIVIL, ART. 530). O REGISTRO IMOBILIÁRIO. ${ }^{41}$

A partir do exposto, e uma vez constatada a inconstitucionalidade das leis municipais que exigem o pagamento antecipado do ITBI, torna-se interessante uma breve análise acerca das eventuais soluções combatentes à evasão fiscal, instituto tão (necessariamente) evitado pelas Fazendas Públicas.

\subsection{Vias de combate à evasão fiscal}

A Constituição Federal, no bojo de seu artigo $3^{\circ}$, traz os objetivos fundamentais da República, quais sejam:

Art. $3^{\circ}$ Constituem objetivos fundamentais da República Federativa do Brasil:

I - construir uma sociedade livre, justa e solidária;

II - garantir o desenvolvimento nacional;

III - erradicar a pobreza e a marginalização e reduzir as desigualdades sociais e regionais;

40 NOGUEIRA, R. W. L. N. Fato gerador da obrigação tributária. Disponível em: <http://jus2. uol.com.br/doutrina/texto.asp?id=6128>. Acesso em: 3 out. 2017.

41 BRASIL. Superior Tribunal de Justiça. REsp 12546/RJ. Publicação DJ 2110/1992. Rel. Min. Humberto Gomes de Brarros. 
IV - promover o bem de todos, sem preconceitos de origem, raça, sexo, cor, idade e quaisquer outras formas de discriminação.

No entanto, tais propósitos não são alcançados sem o devido custeio dos direitos sociais que lhes são peculiares, isto é, a prossecução dos objetivos tipificados no art. $3^{\circ}$ retro, o qual tem por fim a mantença da democracia, não é possível sem a arrecadação de receitas, porquanto seja o sistema fiscal área nuclear na alimentação do desenvolvimento pátrio.

Os eixos basilares em que se assentam a arrecadação tributária têm suas nuances evidenciadas quando da criação das leis infraconstitucionais que a regem, observando a existência da correta repartição do esforço fiscal para que a determinação das exações a serem pagas se dê nos limites legais e constitucionais. Neste sentido, quando da concretude da hipótese de incidência se perfaz o fato jurídico tributário, nasce a obrigação tributária a qual resultará em crédito tributário por meio do lançamento, surgindo então para o contribuinte o dever de recolher a exação tipificada em razão de uma exigência legal. No entanto e em contrapartida, atualmente a Administração tem o dever de aplicar de forma vinculada o produto da arrecadação tributária ${ }^{42}$, ressalvadas as hipóteses legais, como no caso dos impostos, cujo vínculo de receita é vedado, conforme artigo 167, IV, da CRFB/88.

42 Diz-se "atualmente" em razão do Código Tributário Nacional adotou a posição da chamada Teoria Tripartite, enquadrando os tributos, de acordo com a tipologia do artigo $5^{\circ}$, em impostos, taxas e contribuição de melhoria, como reflexo do entendimento predominante à época e seguido pelo legislador. Nesta senda, o artigo $4^{\circ}$ do referido diploma legal determinava que a natureza dos tributos deveria ser definida em razão do fato gerador correspondente à respectiva obrigação, excluindo a destinação da arrecadação tributária dos elementos determinantes para classificá-los. Ocorre que em 1988, quando da promulgação da presente Constituição Federal, o poder constituinte originário trouxe à baila novas espécies tributárias, estas previstas nos artigos 148 e 149, quais sejam, os Empréstimos Compulsórios e as Contribuiçôes Sociais, incluindo as de Intervenção no Domínio Econômico - CIDEs e as de Interesse das Categorias Profissionais. As novas modalidades tributárias evidenciam a superação do critério legal presente no artigo $4^{\circ}$ do CTN, tendo em vista que outros elementos da relação jurídico-tributária - como a destinação legal do produto da sua arrecadação e ainda, sua base de cálculo - passam a fazer parte, de maneira relevante, da identificação de ambas as espécies. $\mathrm{O}$ empréstimo compulsório tem sua instituição permitida unicamente para atender às finalidades constitucionais que justificaram sua instituição (calamidade pública, guerra externa ou sua iminência e investimento de relevante interesse nacional). O mesmo é percebido nas contribuiçôes, que além de serem caracterizadas pela sua finalidade, atuam como instrumento de atuação da União nas respectivas áreas, reforçando a assertiva de que a correta destinação dos recursos arrecadados é fundamental para regular a exigência da indigitada exação. As contribuições não têm um fim em si mesmas, dado que resta para a Administração Pública o 
•• Tributação, direitos fundamentais e desenvolvimento

Os vultosos gastos com a máquina pública desaguam na elevada carga tributária existente na contemporaneidade do país, e, para tanto, é necessário que os contribuintes, sobretudo as pessoas jurídicas, vejam o planejamento tributário como opção preventiva aos eventuais conflitos fiscais que podem ocorrer. Planejar o pagamento de tributos é uma atividade precípua para a permanência de sociedades empresárias em um mercado altamente competitivo e de todo o cidadão cujas finanças são organizadas.

Ocorre que este planejamento não pode se dar de forma ilícita, de forma a burlar as disposições ou vedações legais disciplinadoras do pagamento dos tributos exigidos pelo Estado. Aqui reside a chamada evasão tributária, prática ilegal que se utiliza de institutos defesos por lei, quais sejam, simulação, fraude e sonegação, a fim de se escusar do pagamento de tributos. Por serem afetos ao direito civil, a simulação e a fraude merecem o devido reparo.

$\mathrm{Na}$ inteligência de Silvio Venosa ${ }^{43}$ :

Simular é fingir, mascarar, camuflar, esconder a realidade. Juridicamente, é a prática de ato ou negócio que esconde a real intenção. A intenção dos simuladores é encoberta mediante disfarce, parecendo externamente negócio que não é espelhado pela vontade dos contraentes. As partes não pretendem originalmente o negócio que se mostra à vista de todos; objetivam tão só produzir aparência. Trata-se de declaração enganosa de vontade. (Grifos nossos).

Com a mesma intelecção, discorre acerca da fraude:

A fraude é vício de muitas faces. Está presente em sem-número de situaçôes na vida social e no Direito. Sua compreensão mais acessível é a de todo artifício malicioso que uma pessoa emprega com intenção de transgredir o Direito ou prejudicar

dever de aplicar os referidos produtos nos campos ensejadores de sua criação. Contudo, todo o exposto acima não é válido para receitas provenientes de impostos, em razão no disposto no artigo 167, IV da Constituição Federal de 1988. Os impostos não podem ter suas arrecadações afetas a órgãos, fundos ou despesas. A vedação é afastada apenas nas hipóteses expressamente ressalvadas pelo dispositivo, as quais tratam do Sistema Único de Saúde e da manutenção e desenvolvimento do ensino. A matéria em comento já foi objeto de diversas açōes do controle concentrado de constitucionalidade, dentre elas a que julgou inconstitucional a vinculação de parte da receita do ICMS do estado do Paraná a um programa implementado pelo estado visando ao incentivo da cultura. Por tal motivo também é considerada inconstitucional a majoração de impostos com vinculação a uma finalidade específica. Assim, a destinação legal do produto da arrecadação dos tributos deve ser considerada de acordo com a espécie tributária em análise, contudo, em virtude das determinaçôes constitucionais mencionadas, não mais pode ser excluída do rol de elementos relevantes para classificar os tributos.

43 VENOSA, Sílvio de Salvo. Direito civil: parte geral. 10. ed. São Paulo: Atlas, 2010, p. 515. 
interesses de terceiros. (...) $\mathrm{Na}$ fraude, o negócio jurídico é real, verdadeiro, mas feito com o intuito de prejudicar terceiros ou burlar a lei. ${ }^{44}$

Imperioso mencionar que a evasão tributária reverbera na esfera penal, ao passo que, quando da prática da sonegação fiscal - esta sendo configurada como uma conduta transgressora - o contribuinte comete crime contra a ordem tributária. Nos dizeres de James Marins ${ }^{45}$, o sujeito ativo dos crimes tributários é definido nos seguintes termos:

Pratica o crime tributário quem suprime ou reduz tributo por meio de supressão de informações ou por meio de informação falsa, ou através de inserção de dado inexato em livros ou documentos fiscais, ou mesmo pela falsificação ou alteração de nota fiscal ou negar-se a emiti-la, ou através de outras condutas consideradas fraudulentas.

A evasão fiscal está tipificada na Lei nº 8137/90 - Lei dos Crimes Contra a Ordem Tributária, Econômica e Contra as Relações de Consumo, que disserta em seus arts. $1^{\circ}$ e $2^{\circ}$ :

Art. $1^{\circ}$ Constitui crime contra a ordem tributária suprimir ou reduzir tributo, ou contribuição social e qualquer acessório, mediante as seguintes condutas:

I - omitir informação, ou prestar declaração falsa às autoridades fazendárias;

II - fraudar a fiscalização tributária, inserindo elementos inexatos, ou omitindo operação de qualquer natureza, em documento ou livro exigido pela lei fiscal;

III - falsificar ou alterar nota fiscal, fatura, duplicata, nota de venda, ou qualquer outro documento relativo à operação tributável;

IV - elaborar, distribuir, fornecer, emitir ou utilizar documento que saiba ou deva saber falso ou inexato;

$\mathrm{V}$ - negar ou deixar de fornecer, quando obrigatório, nota fiscal ou documento equivalente, relativa à venda de mercadoria ou prestação de serviço, efetivamente realizada, ou fornecê-la em desacordo com a legislação.

Parágrafo único. A falta de atendimento da exigência da autoridade, no prazo de 10 (dez) dias, que poderá ser convertida em horas em razão da maior ou menor complexidade da matéria ou da dificuldade quanto ao atendimento da exigência, caracteriza a infração prevista no inciso "V".

"Art. 2o Constitui crime da mesma natureza:

I - fazer declaração falsa ou omitir declaração sobre rendas, bens ou fatos, ou empregar outra fraude, para eximir-se, total ou parcialmente, de pagamento de tributo;

44 Ibidem, p. 445.

45 MARINS, James. Elisão tributária e sua regulação. São Paulo: Dialética, 2002, p. 31. 
-. Tributação, direitos fundamentais e desenvolvimento

II - deixar de recolher, no prazo legal, valor de tributo ou de contribuição social, descontado ou cobrado, na qualidade de sujeito passivo de obrigação e que deveria recolher aos cofres públicos;

III - exigir, pagar ou receber, para si ou para o contribuinte beneficiário, qualquer percentagem sobre a parcela dedutível ou deduzida de imposto ou de contribuição como incentivo fiscal;

IV - deixar de aplicar, ou aplicar em desacordo com o estatuído, incentivo fiscal ou parcelas de imposto liberadas por órgão ou entidade de desenvolvimento;

$\mathrm{V}$ - utilizar ou divulgar programa de processamento de dados que permita ao sujeito passivo da obrigação tributária possuir informação contábil diversa daquela que é, por lei, fornecida à Fazenda Pública.

$\mathrm{Na}$ evasão a prática deve ser notadamente ilícita, podendo sê-la tanto por omissão, como por ação. À luz do ensinamento de Sampaio Dória ${ }^{46}$, a evasão pode ser classificada como imprópria, quando se caracterizar pela abstenção à incidência e assim evitar que ocorram os atos tributários ou pela transferência econômica; e por inação, que poderia ser vista tanto na modalidade dolosa (pela via da sonegação, da falta ou ainda do atraso de recolhimento), como na modalidade não dolosa (por ignorância do dever fiscal ou desconhecimento sobre a legislação). Classifica também a evasão comissiva da seguinte forma: atitude ilícita (por meio de fraude, simulação e conluio); e atitude lícita ou legítima (elisão ou economia fiscal).

Roque Carrazza ${ }^{47}$ elenca uma miríade de comportamentos omissivos e comissivos que se praticados pelo contribuinte, resultam na evasão fiscal, nos termos do fragmento abaixo:

A imaginação criadora do homem tem, ao longo do tempo, urdido vários comportamentos que levam ao não pagamento do tributo, a uma tributação menos onerosa ou, quando pouco, à procrastinação do cumprimento da obrigação tributária. Facilmente podemos dar exemplos típicos destas condutas reprováveis. Um deles é o da venda de mercadoria sem emissão da imprescindível nota fiscal (venda a descoberto de nota fiscal), levada a efeito com o evidente intuito de deixar de documentar a operação mercantil realizada e, assim, com maior facilidade, ilaquear o Fisco. Outro, é o da não declaração de rendimentos, que leva à sonegação do imposto respectivo (o imposto sobre a renda). Outro, ainda, é o da lavratura de escritura de venda e compra de imóvel, nela fazendo consignar preço menor do que o efetivamente praticado, com o propósito de diminuir o quantum de ITBI a pagar. Enfim, os exemplos de práticas

46 DÓRIA, Antonio Roberto Sampaio. Elisão e evasão fiscal. São Paulo, RT, 1977, p. 20.

47 CARRAZZA, Roque Antonio. Curso de direito constitucional tributário. 26. ed. São Paulo: Malheiros, 2011, p. 349. 
dolosas, omissivas ou comissivas, que levam à evasão fiscal, poderiam ser multiplicados, já que são legião.

Controlar a evasão é uma tarefa árdua que encontra obstáculos no sentimento generalizado da coletividade de que os recursos arrecadados pelo Estado não são devidamente aplicados nas atividades que significam a contraprestação pelo pagamento dos tributos. No entanto, quanto maior a evasão, maiores os prejuízos sofridos pelos próprios contribuintes.

Alícia Bárcena, Secretária Executiva da "Comisión Económica para América Latina y Caribe" da Organização das Naçôes Unidas divulgou no artigo intitulado Paraisos fiscales y el financiamiento de la Agenda 2030 dados provenientes da América Latina, território em que a estimativa de evasão de Imposto de Renda no ano de 2015 (de pessoas físicas e jurídicas) foi da ordem de 220 milhões de dólares equivalentes a 4,3\% do PIB, conforme trecho a seguir:

En América Latina la CEPAL ha estimado que la evasión al impuesto a la renta de empresas y personas físicas es del orden de 220.000 millones de dólares, equivalente a 4,3\% del producto interno bruto (PIB) regional en 2015. Si a esto sumamos la evasión del impuesto al valor agregado (IVA) - de 120.000 millones de dólares- la cifra de evasión total llega a 340.000 millones de dólares, equivalente a un monto cercano a $6,7 \%$ del PIB. ${ }^{48}$

Na direção tomada, emerge o planejamento tributário como possibilidade de ordenar e sistematizar a repartição financeira e obrigações fiscais dos sujeitos passivos, por consistir em uma ferramenta de atuação legal. Leciona James Marins ${ }^{49}$ acerca do planejamento tributário:

Denomina-se planejamento fiscal ou tributário lato sensu a análise do conjunto de atividades atuais ou dos projetos de atividades econômico-financeiras do contribuinte (pessoa física ou jurídica), em relação ao seu conjunto de obrigações fiscais com o escopo de organizar suas finanças, seus bens, negócios, rendas e demais atividades com repercussões tributárias, de modo que venha a sofrer o menor ônus fiscal possível. O planejamento tributário pode se dar através da adoção de variadas formas. Pode ser meio do uso de mecanismos administrativos próprios como o redirecionamento de atividades, a reorganização contábil e a reestruturação societária, ou por intermédio de mecanismos fazendários de elisão induzida ou permitida, como a utilização de opção para regimes fiscais mais benéficos, e também o aproveitamento de

48 COMBATE à sonegação fiscal é essencial para financiar metas da ONU, diz CEPAL. Disponível em: <https://nacoesunidas.org/combate-a-sonegacao-fiscal-e-essencial-para-financiar-metas-da-onu-diz-cepal/>. Acesso em: 24 jul. 2017.

49 MARINS, James. Op. cit., p. 33-34. 
•• Tributação, direitos fundamentais e desenvolvimento

prerrogativas e incentivos fiscais gerais ou setoriais, como imunidades, isenções, zonas francas, incentivos estaduais ou municipais, ou até mesmo através da escolha de tratados internacionais.

Quando o contribuinte busca realizar um planejamento tributário, poderá se deparar com a elisão fiscal que, em seu gênero, sempre se atentará para a licitude dos atos praticados na busca pela melhora dos ônus incidentes em suas atividades sempre antes de praticado o fato imponível. A elisão encontra juridicidade no planejamento tributário e se coaduna com o atual degrau da ciência jurídica pátria, principalmente sob o prisma do constitucionalismo moderno, vez que este rechaça interpretações que que se abstenham da realidade fática, subjacente às formas jurídicas. Assim, os contribuintes adotam determinadas medidas estritamente jurídicas ou econômicas com o fito de reduzir seus custos fiscais e, uma vez minoradas estas parcelas, seu saldo ao final do período de apuração será melhor do que aquele no qual a carga tributária recairia com todo seu peso.

Andrade Filho ${ }^{50}$ aponta que a elisão fiscal "envolve a escolha, entre alternativas válidas, de situações fáticas ou jurídicas que visem reduzir ou eliminar ônus tributários, sempre que isso for possível nos limites da ordem jurídica”.

Logo, condutas que aparentemente se enquadrariam nos moldes da elisão fiscal, podem ser consideradas inadequadas, merecendo atenção. $\mathrm{O}$ contribuinte, ao lançar mão de planejar suas finanças, não transgrediu qualquer regra positivada, - ao contrário, demonstrou inteligência e precaução, de forma que não caberia caracterizar as práticas por ele adotadas como evasão fiscal, ab initio. Contudo, caso abuse dos mecanismos a ele disponíveis para tanto e de seu direito de economizar no pagamento de impostos, adotando operações desprovidas de finalidade fático-econômicas a elas inatas, através da utilização de negócio jurídico indireto ou de abuso de forma, terá o seu planejamento deslocado para a prática evasiva. Desta feita, uma das formas de combater a evasão fiscal é a interpretação jurídica, que com os influxos da abertura de valores da justiça e igualdade, denotados pelos princípios da capacidade contributiva e da isonomia.

Ademais, o ITBI conta como modalidade de lançamento o lançamento por declaração, previsto no art. 147 do CTN. Nesta forma de lançar o tributo o sujeito passivo possui a obrigação acessória de prestar à autoridade Administrativa infor-

ANDRADE FILHO, Edmar Oliveira. Imposto de renda das empresas. São Paulo: Atlas, 2007, p. 128. 
maçōes acerca da matéria fática, indispensáveis para a consagração da constituição do crédito. No caso em tela, seria esta a modalidade ideal para evitar abusos por parte do Fisco municipal em relação ao contribuinte, visto que caso este não declare a alienação do imóvel e o respectivo registro, o lançamento não se aperfeiçoará in totum. Pode, ainda, ocorrer a sub-rogação do lançamento por declaração pelo lançamento de ofício, caso o fato imponível ocorra e o imposto não seja pago, conforme a doutrina.

Sobrevém, contudo, a notada ânsia dos municípios em evitar o não pagamento do imposto, de modo que acabam por eivar de inconstitucionalidade suas leis municipais que disciplinam o tributo ora em estudo. Desta feita, outra via de combate à evasão passível de adoção pelo município seria o próprio lançamento de ofício por primeiro, excluindo-se o lançamento por declaração. Isto porque, além das obrigações dos notários e cartorários previstas na lei 8935/94, está a contribuição com a fiscalização municipal, corroborando com o argumento segundo o qual se demonstra mais justo e correto que o cartório de registro de imóveis estabeleça comunicação direta com a Administração Municipal a fim de informá-la acerca da ocorrência do fato gerador da exação para que então se proceda ao lançamento de ofício ao invés de ser editada uma lei municipal tributária maculada pela inconstitucionalidade por exigir o pagamento do tributo em momento prévio ao da ocorrência de seu fato gerador.

A razão pela qual existe a possibilidade do município lançar o ITBI de ofício nos casos da verificação do fato gerador sem pagamento é justamente evitar que se opere o fenômeno da decadência tributária, pois, conforme o art. 174 do CTN, o lapso temporal para a constituição definitiva do crédito tributário é de cinco anos contados da ocorrência do fato gerador. Em sendo puramente o lançamento por declaração, caso o sujeito passivo não declare o tributo extingue para o fisco o direito de constituir o crédito. Não havendo constituído o crédito, não há o objeto para inscrição em dívida ativa que enseje a possível execução fiscal. Se, pois, é este o fundamento basilar da cobrança do imposto de maneira inconstitucional e antecipada, observa-se no lançamento de ofício prima facie, solução mais correta até mesmo para evitar que as leis municipais precisem ser submetidas ao controle difuso de constitucionalidade pela via da Arguição de Descumprimento de Preceito Fundamental, caso ocorrido com o município de Uberlândia que será discorrido no tópico abaixo. 
•• Tributação, direitos fundamentais e desenvolvimento

\subsection{ADPF 349 e seus desdobramentos}

A Arguição de Descumprimento de Preceito Fundamental (ADPF 349) ajuizada no Supremo Tribunal Federal, cuja relatoria foi do Ministro Marco Aurélio, questionou dispositivos da Lei n. 4.871/1989 do município de Uberlândia - MG, que disciplinava a cobrança do Imposto sobre a Transmissão de Bens Imóveis em âmbito municipal. Os artigos 12 e 14 da norma tornam obrigatória a cobrança de ITBI pela Fazenda Pública do Município de Uberlândia antes da transmissão dos bens imóveis e dos direitos a eles relativos.

De acordo com o então procurador-geral da República, Rodrigo Janot, autor da demanda, os dispositivos legais foram impugnados em razão de apresentarem contrariedade aos preceitos fundamentais dispostos no artigo 156, inciso II, da Constituição Federal (o qual estabelece que o fato gerador do tributo é a transmissão do domínio dos referidos bens) e no artigo $5^{\circ}$, caput e inciso XXII, da CF, que consagra o direito de propriedade.

O procurador afirma ser inviável a cobrança do ITBI antes da ocorrência do seu fato gerador, que se procede, conforme todos os capítulos acima estruturados, de acordo com o Código Civil, no momento do registro do título no Registro de Imóveis. Na intelecção de Janot: "Não havendo o registro da escritura definitiva em cartório, inexiste transmissão da propriedade e, por conseguinte, não ocorre o fato gerador, elemento imprescindível para a exigibilidade do tributo, na forma do ordenamento jurídico brasileiro" 51

Além da cobrança antecipada, a norma vai além e também impede que escrivães, tabeliães, oficiais de notas, de registro de imóveis e de títulos e documentos, assim como serventuários da Justiça, pratiquem quaisquer atos de transmissão de bens imóveis sem a prévia apresentação dos comprovantes originais do pagamento do referido tributo, constituindo uma flagrante afronta ao direito de propriedade constante da Carta Magna. Rodrigo Janot explicou que

Embora o objetivo do legislador municipal de Uberlândia tenha sido claramente o de garantir o pagamento de ITBI por parte dos contribuintes, sua ânsia arrecadatória acabou por incorrer em manifesta inconstitucionalidade, inclusive por haver resultado em reprovável violação ao direito de propriedade, o qual, embora não seja direito fundamental absoluto, não pode sofrer restriçōes senão com fundamento em outros

Ação questiona lei municipal de Uberlândia que estabelece a cobrança de ITBI antes da transmissão dos bens. Disponível em: <http://www.stf.jus.br/portal/cms/verNoticiaDetalhe. asp?idConteudo=293135>. Acesso em: 20 nov. 2017. 
princípios constitucionais, jamais com base exclusiva em interesses tributários e financeiros..$^{52}$

Por fim, o procurador-geral sustentou a inconstitucionalidade dos dispositivos mencionados por usurpação de competência privativa da União ao disciplinar matéria afeta ao direito civil brasileiro preconizada no artigo 22, inciso I, da Lei Maior. Requereu, portanto, assistido de razão, a procedência do pedido para declarar a inconstitucionalidade dos artigos 12 e 14 da Lei n. 4.871/1989, do município de Uberlândia.

\section{CONCLUSÃO}

Em arremate, conclui-se o presente estudo no sentido de discordar com a cobrança do Imposto sobre Transmissão de Bens Imóveis Inter Vivos por parte da Fazenda Pública Municipal quando da celebração do negócio jurídico de compra e venda, situação reiteradamente observada no país. Isto porque, ao cobrar o ITBI de forma antecipada o Fisco municipal viola frontalmente a Constituição da República cujas normas - responsáveis por inspirar todo e qualquer dispositivo infraconstitucional - garantem o exercício do direito real de propriedade. Para tanto, deslindou-se acerca da propriedade, seu conceito e seus atributos.

Muito embora este não seja direito absoluto, não se pode convir que sofra limitações ou restriçôes não corroboradas em outros princípios constitucionais, isto é, não pode haver inobservância do que preconiza a Carta da República para atender interesses econômico- financeiros dos poderes públicos.

Estudou-se, pois, a importância do planejamento tributário dos entes políticos como possível via utilizada no combate à evasão e fiscal, e proposta a alternativa de instituição do lançamento de ofício como primeira modalidade de constituição do crédito do ITBI, o que poderia ser possível através de comunicação entre cartório e fisco municipal, a fim de se evitar que fosse cobrado o tributo em momento prévio ao da concretização de sua hipótese de incidência, tendo em vista que o Cartório de Registro de Imóveis é o local onde ocorre o fato imponível do imposto.

Recolher o Imposto Sobre Transmissão de Bens Imóveis em momento anterior à ocorrência do seu fato imponível é uma notória tentativa Contudo, ao ignorar que a efetiva transferência da propriedade do imóvel ainda não se perfez vicia a ordem de cobrança do referido imposto de inconstitucionalidade.

52 Idem. 
-. Tributação, direitos fundamentais e desenvolvimento

Neste sentido, é necessário que os Municípios utilizem formas diversas de combate às indesejadas fraudes tão prejudiciais ao erário, mas que sejam eficazes, sem que seja preciso macular suas leis tributárias de inconstitucionalidade e por em xeque o direito real de propriedade.

O núcleo em torno do qual volveu este trabalho foi a legalidade, o cumprimento do que está efetivamente disposto em lei. É real a necessidade do recolhimento do imposto ora estudado, bem como de todos os outros tributos sem os quais é impossível o custeio de qualquer medida ou direito social postos à sociedade. $\mathrm{O}$ que se deve priorizar não é nem a desoneração completa do contribuinte, nem o pagamento a qualquer custo dos tributos, mas a cobrança destes em momento correto conforme disciplinado em lei, sem práticas viciadas por qualquer das partes envolvidas na relação jurídico-tributária. Se há prejuízo fiscal causado pelo não pagamento do tributo, providências legais necessitam ser tomadas. Ir até a lei tributária municipal e alterar o momento de ocorrência do fato gerador de um imposto o qual já encontra previsão na Constituição não irá solver o problema, apenas torná-lo maior, pois ao cobrar o tributo antecipadamente a Fazenda Municipal crê solucionar a perda da receita não arrecadada outrora, ao passo que edita uma lei inconstitucional por violar o direito de propriedade, por usurpar competência privativa da União, e por ignorar a hipótese de incidência já prevista para o ITBI.

Por esta razão, este trabalho foi escrito em atenção à primazia da Constituição Federal, único caminho pelo qual é possível se atingir o mínimo de desenvolvimento para o país, não apenas, mas principalmente, em âmbito fiscal.

\section{REFERÊNCIAS}

A posse e a propriedade no novo Código Civil. Disponível em: <http://www.buscalegis. ufsc.br/revistas/files/anexos/7992-7990-1>-PB.htm. Acesso em: 23 set. 2017.

Ação questiona lei municipal de Uberlândia que estabelece a cobrança de ITBI antes da transmissão dos bens. Disponível em:<http://www.stf.jus.br/portal/cms/verNoticiaDetalhe. asp? idConteudo=293135>. Acesso em: 20 nov. 2017.

ANDRADE FILHO, Edmar Oliveira. Imposto de renda das empresas. São Paulo: Atlas, 2007.

ATALIBA, Geraldo. Hipótese de incidência tributária. 6. ed. São Paulo: Malheiros, 2006. BANDEIRA DE MELLO, Celso Antônio. Curso de direito administrativo. 22. ed. São Paulo: Malheiros, 2007. 
BARRETO, Paulo Ayres. Imposto Sobre Transmissão de Bens Imóveis (ITBI). Disponível em: <https://disciplinas.stoa.usp.br/pluginfile.php/365113/mod_resource/content/1/ Aula\%2004\%20-\%20DEF0516\%20-\%20ITBI.pdf>. Acesso em: 8 nov. 2017.

BEVILAQUA, Clóvis. Direito das coisas: prefácio de Francisco Cesar Asfor Rocha. Brasília: Imprenta, Senado Federal - Conselho Eiditorial, 2003 (Coleção história do direito brasileiro. Direito civil 7).

BRASIL. Código Civil. Lei 10.406 de 10 de Janeiro de 2002. Institui o Código Civil. Disponível em: <http://www.planalto.gov.br/ccivil_03/leis/2002/L10406.htm>.

BRASIL. Código de Tributário Nacional. Lei n. 5. 172, de 25 de outubro de 1966. Disponível em: <http://www.planalto.gov.br/ccivil_03/leis/L5172Compilado.htm>.

BRASIL. Constituição Federal de 1988. Promulgada em 5 de outubro de 1988. Disponível em: <http://www.planalto.gov.br/ccivil_03/constituicao/constituição.htm>.

BRASIL. Superior Tribunal de Justiça. REsp 12546 /RJ. Publicação DJ 2110/1992. Rel. Min. Humberto Gomes De Barros.

BRASIL. Supremo Tribunal Federal. Agravo Regimental em Recurso Extraordinário com Agravo 805859/RJ. Publicação DJe 09/03/2015. Rel. Min. Luis Roberto Barroso.

BRASIL. Supremo Tribunal Federal. Agravo Regimental em Recurso Extraordinário com Agravo 805859/RJ. Publicação DJe 09/03/2015. Rel. Min. Luis Roberto Barroso.

BRASIL. Supremo Tribunal Federal. ARE 807.255 AgR/RJ. Publicação DJe 03/11/2015. Rel.: Min. Edson Fachin.

BRASIL. Supremo Tribunal Federal. ARE 798.004/RJ. Publicação DJe 07/052014. Rel. Min. Teori Zavascki.

BRASIL. Supremo Tribunal Federal. Habeas Corpus 77530/RS. Publicação DJe 18/09/1998. Rel. Min. Sepúlveda Pertence.

BRASIL. Supremo Tribunal Federal. Recurso Extraordinário 562045/RS. Publicação DJe 27/11/2013. Rel. Min Ricardo Lewandowski.

BRASIL. Supremo Tribunal Federal. Recurso Extraordinário 75124/DF. Publicação DJe 04/05/1981. Rel. Min. Antonio Neder.

CARDOSO, Patrícia Silva. Função socioambiental e intervenção do Estado na propriedade: limites e possibilidades à luz da garantia constitucional da propriedade privada. 2016. 348 f. (Doutorado em Direito) - Faculdade de Direito, Universidade do Estado do Rio de Janeiro, 2016.

CARRAZZA, Roque Antonio. Curso de direito constitucional tributário. 26. ed. São Paulo: Malheiros, 2011.

CARVALHO, Paulo de Barros. Curso de direito tributário. 23. ed. São Paulo: Saraiva, 2010.

Combate à sonegação fiscal é essencial para financiar metas da ONU, diz CEPAL. Disponível em: <https://nacoesunidas.org/combate-a-sonegacao-fiscal-e-essencial-parafinanciar-metas-da-onu-diz-cepal/>Acesso em: 24 jul. 2017. 
•• Tributação, direitos fundamentais e desenvolvimento

COSTA, Regina Helena. Instrumentos tributários para implementação da política urbana (art. $7^{\circ}$ ). In: DALLARI, Adilson Abreu; FERRAZ, Sérgio (Coord.). Estatuto da cidade: comentários à lei federal 10.257/01. São Paulo: Malheiros, 2003.

DÓRIA, Antonio Roberto Sampaio. Elisão e evasão fiscal. São Paulo, RT, 1977.

DUTRA, Eugênio Klein. Sistemas de transferência da propriedade imóvel. Disponível em: <http://domtotal.com/direito/pagina/detalhe/33189/sistemas-de-transferencia-dapropriedade-imovel>. Acesso em: 20 set. 2017.

FARIAS, Cristiano Chaves de; ROSENVALD, Nelson. Curso de direito civil. 12 ed. conforme novo CPC. Rio de Janeiro: Juspodivm, 2016. v. V: Reais.

GALGANO, Francesco. Diritto privato. 6. ed. Padova: Cedam, 1990.

GOMES, Orlando. Direitos reais. 9. ed. Rio de Janeiro: Forense, 1985.

KELSEN, Hans. Teoria geral do direito e do estado. Tradução de Luis Carlos Borges. 3. ed. São Paulo: Martins Fontes, 2000.

LANDIM, Francisco. A propriedade imóvel na teoria da aparência. São Paulo: CD Livraria e Editora, 2001.

LOUREIRO, Francisco Eduardo. A propriedade como relação jurídica complexa. Rio de Janeiro: Renovar, 2003.

MARINS, James. Elisão tributária e sua regulação. São Paulo. Dialética, 2002.

MENDES, João Augusto Ribeiro. O conceito de propriedade. Dissertação (Mestrado) Universidade Federal de Santa Catarina, Centro de Ciências Jurídicas. Florianópolis, 1994.

MUNIZ, Francisco José Ferreira. Embargos de terceiros à penhora. A questão da posse do promitente comprador. In: Textos de Direito Civil. Curitiba: Juruá, 1998.

NOGUEIRA, R.W.L.N. Fato gerador da obrigação tributária. Disponível em: <http:// jus2.uol.com.br/doutrina/texto.asp?id=6128>. Acesso em: 3 out. 2017.

OBERTO, Paula Baptista. Direito agrário: função social da propriedade; sua evolução e história. Disponível em: <http://www.iuspedia.com.br> Acesso em: 9 out. 2017.

PAULSEN, Leandro. Curso de direito tributário completo. 4. ed. rev. atual. e ampl. Porto Alegre: Livraria do Advogado, 2012.

PEREIRA, Caio Mário da Silva. Instituições de direito civil. 21. ed. Rio de Janeiro: Forense, 2006. v. IV: Direitos reais.

PEREIRA, Lafayette Rodrigues. Direito das coisas: prefácio de Sálvio de Figueiredo. Brasília: Imprenta, Senado Federal - Conselho Eiditorial, 2004 (Coleção história do direito brasileiro. Direito civil 8).

SABBAG, EDUARDO. Manual de direito tributário. 8. ed. São Paulo: Saraiva, 2016.

VENOSA, Sílvio de Salvo. Direito civil: parte geral. 10. ed. São Paulo: Atlas, 2010. 